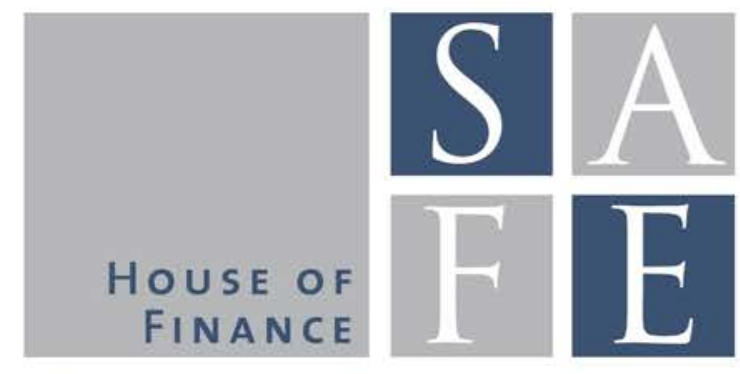

WORKING PAPER SERIES

Pinar Topal

\title{
Fiscal stimulus and labor market flexibility
}

SAFE Working Paper No. 90

SAFE I Sustainable Architecture for Finance in Europe A cooperation of the Center for Financial Studies and Goethe University Frankfurt 


\section{Non-Technical Summary}

The current global economic and financial crisis has drawn the attention of the academic and policy circle to the role and efficiency of fiscal policy and brought it to the center of the debate. As nominal interest rates reached the zero lower bound and the traditional monetary transmission mechanism failed to deal with the demand contraction, fiscal stimulus packages have been suggested as a better tool to boost economies and encounter the remedies of the experienced downturn. Thus, the large-scale fiscal stimulus packages have been implemented around the globe. A closer look at the composition of these packages suggests that the advanced economies strongly focused on labour market measures to cushion the fall in economic output and employment by following the policy advices on necessity of labour market deregulation.

Despite of the ongoing debate on the efficiency of fiscal policy implications and labour market reforms, there is no clear consensus about their effectiveness. None of the existing studies has investigated on this issue so far and focused on both the ability of government expenditure shocks to boost output and reduce unemployment and its effectiveness on different labour market institutions. To fill the gap, this paper contributes to the literature by investigating whether fiscal stimulus impact differs for flexible and rigid labour markets. This question is crucial to be answered in order to understand the role of different labour market structures in determining the success of fiscal stimulus. By proxying the flexibility of labour markets with employment protection legislation indicator of OECD, I study whether government spending shocks are able to stimulate economic growth more in the markets with weaker employment protections than the ones with stricter regulations and additionally the impact of fiscal stimulus on unemployment.

My empirical results indicate significant differences between rigid and flexible labour markets regarding the impact of the fiscal stimulus on output and unemployment. While the impulse response of real GDP to a government spending shock is positive and more effective in flexible labour markets, it has less impact in the rigid ones. The results show that as the labour markets get more flexible, the impact on the output gets more persistent. It is also found that fiscal stimulus leads to higher overall unemployment in highly regulated countries. This finding confirms the evidence from the existing literature implying that rigid labour market structure is associated with low job creation rate for the unemployed individuals and increasing labour market flexibility has a significant negative effect on unemployment rate. As labour markets get flexible, government expenditure shocks trigger a stronger increase in the new job creation rate, which leads to reduction in the overall unemployment.

My findings emphasize that fiscal stimulus may not be able to help rigid labour markets in boosting the economic growth and reducing the unemployment rate. As high employment protections in the labour markets affect the unemployment rate negatively by reducing job finding and creation rates, it is suggested that the flexibility of labour markets plays a crucial role in the success of fiscal policies. In case of high employment protection and heavily 
regulated markets, employers may find it less profitable to react to fiscal stimuli due to the restrictions on the hiring and firing processes. This restricts the effectiveness of the fiscal policy implementations in labour markets that are subject to rigid structures. Therefore, in order to benefit more from fiscal stimulus, further deregulation in the labour markets may be taken as a policy advice for the economies such as, the European periphery, namely Italy, Portugal and Spain, which are subject to strict regulations. 


\title{
Fiscal stimulus and labor market flexibility *
}

\author{
Pinar Topal ${ }^{\dagger}$ \\ Goethe University Frankfurt
}

March 3, 2015

\begin{abstract}
This paper investigates whether a fiscal stimulus implies a different impact for flexible and rigid labour markets. The analysis is done for 11 advanced OECD economies. Using quarterly data from 1999 to 2013, I estimate a panel threshold structural VAR model in which regime switches are determined by OECD's employment protection legislation index. My empirical results indicate significant differences between rigid and flexible labour markets regarding the impact of the fiscal stimulus on output and unemployment. While the impulse response of real GDP to a government spending shock is positive and more effective in flexible labour markets, it has less impact in the rigid ones. Moreover, it is found that a fiscal stimulus leads to higher overall unemployment in highly regulated countries.
\end{abstract}

JEL codes: E62, H30, J01, J08

Keywords: fiscal policy, labour economics, labour market policies, threshold vector auto-regressive models, panel VAR, non-linear VAR, impulse analysis

* This paper was partially conducted during my visit as a Ph.D. intern at the Research Centre of Deutsche Bundesbank. It is a part of the research program of the Center "Sustainable Architecture for Finance in Europe" (SAFE). Project funding (\#2014-11531) is gratefully acknowledged. I thank my advisor Alfons J. Weichenrieder for valuable advice and support. I am also grateful to Pooyan Amir Ahmadi, Michael Binder, Fabio Canova, Shafik Hebous, Norbert Metiu, Atılım Seymen and the participants of the 8th RGS Doctoral Conference in Economics, DIW Macroeconometric Workshop 2014, the Internal Research/Doctoral and Macro Brown Bag Seminars at the Goethe University Frankfurt, the Spring Meeting of Young Economists 2014, the 13th Annual Conference of European Economic and Finance Society, Istanbul Conference of Economics and Finance, and the researchers at the Economics Department of Deustche Bundesbank for helpful comments and suggestions. The usual disclaimer applies.

${ }^{\dagger}$ Goethe University Frankfurt, Chair of Public Finance,Theodor-W.-Adorno-Platz 4, 60323 Frankfurt am Main, Germany. email: koez@wiwi.uni-frankfurt.de 


\section{Contents}

1 Introduction

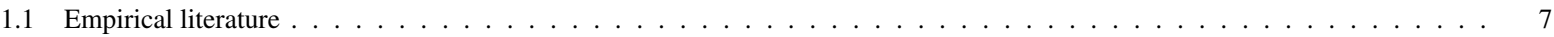

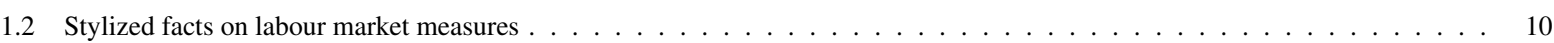

2 Data 13

3 Methodological issues $\quad 15$

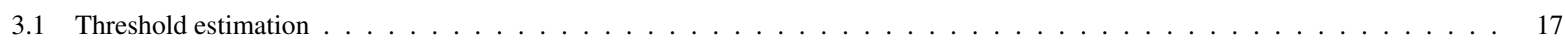

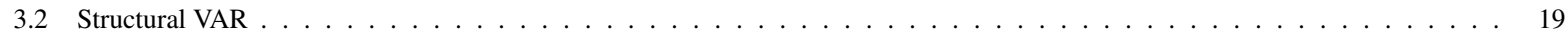

3.2 .1 Identification . . . . . . . . . . . . . . . . . . . . . . . . . . . . . . . . . . . . . 19

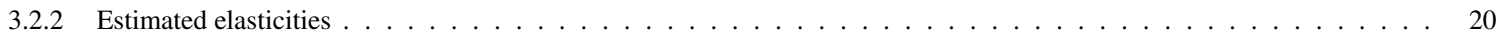

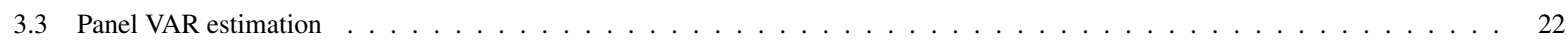

4 Results

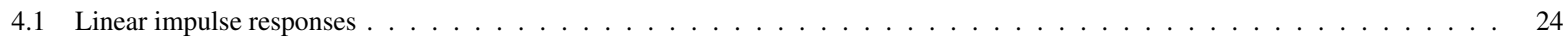

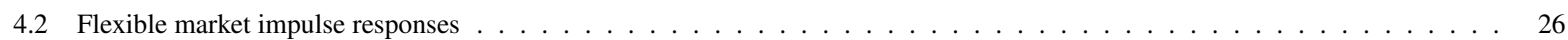

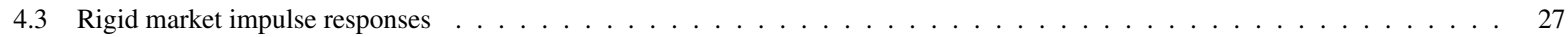

4.4 Comparison of flexible and rigid labour markets $\ldots \ldots \ldots \ldots \ldots \ldots \ldots$

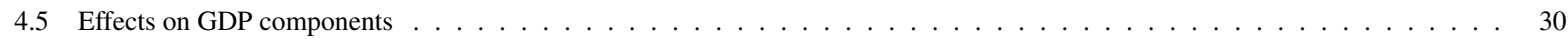

5 Robustness Checks

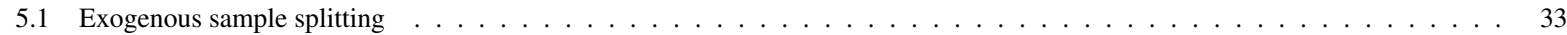

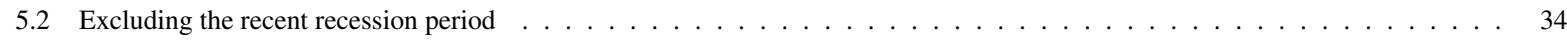

6 Conclusion $\quad 36$

7 Appendix $\quad 38$

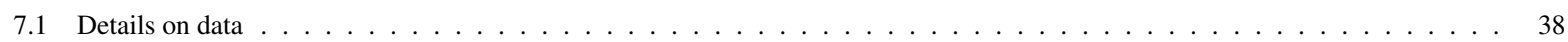




\section{Introduction}

The current global economic and financial crisis has drawn the attention of the academic and policy circle to the role and efficiency of fiscal policy and brought it to the center of the debate. As nominal interest rates reached the zero lower bound and the traditional monetary transmission mechanism failed to deal with the contraction of demand, fiscal stimulus packages have been suggested as a better tool to boost economies and encounter the remedies of the experienced downturn. Thus, the large-scale fiscal stimulus packages have been implemented around the globe. A closer look at the composition of these packages suggests that the advanced European countries strongly focused on labour market measures to cushion the fall in economic output and employment. In particular, most of the European countries with relatively rigid labour markets, which are subject to strict employment protections, such as Germany and Italy, have invested to decrease job destruction, stimulate job creation and tried to cope with the problem of labour market segmentation. On the other side, flexible labour markets with loose employment protections, such as the US ${ }^{1}$ and the UK, have acted interventions to facilitate job creation (Faia et al., 2013). As a remedy for the current downturn, the advocates of labour market reforms support policies on relaxing the employment protections. They claim that weakening the restrictions on the labour markets reduces the dismissing costs and encourages the employers to hire more workers (Heyes and Lewis, 2013). ${ }^{2}$

Despite of the ongoing debate on the efficiency of fiscal policy implications and labour market deregulation, there is no clear consensus about their effectiveness. There are already some studies finding evidence on the impact of government expenditure on GDP and consumption (Blanchard and Perotti, 2002; Auerbach and Gorodnichenko, 2012; Ilzetzki et al. 2013), but on the other side, the fiscal policy implications for unemployment rate and labour market outcomes in general has not received much of attention in the literature (Monacelli et al. 2010). Since the structure of

\footnotetext{
${ }^{1}$ The American Recovery and Reinvestment Act (ARRA) emphasizes the ability of fiscal policy to generate jobs and thus, raise employment in the economy (Monacelli et al., 2010).

${ }^{2}$ Heyes and Lewis (2013) argue that the suggestion of weakening the employment protections is not a new debate among the policy markers. Starting for 1980s the IMF and OECD have suggested that the solution to jobs growth lay in relaxing the rules in the labour markets.
} 
the labour markets, such as the tightness of rules and regulations, vary significantly among the advanced OECD countries and these regulations and restrictions may have crucial influence on the outcome of the policy implications, it becomes essential to address whether the fiscal stimulus impact vary in different labour market regimes. None of the existing studies has investigated on this issue so far and focused on both the ability of government expenditure shocks to boost output and reduce unemployment and its effectiveness on rigid and flexible labour markets.

To fill this gap in the literature, this paper focuses on the effects of government expenditure shock on economic activity and unemployment by taking into account the different labor market structures, using a non-linear VAR approach. It investigates whether fiscal stimulus impact differs for flexible and rigid labour markets. This question is crucial to be answered in order to understand the role of different labour market structures in determining the success of fiscal stimulus. By measuring the flexibility of labour markets with employment protection levels, I study whether government spending shocks are able to stimulate economic growth more in the markets with weaker employment protections than the ones with stricter regulations. As argued in Heyes and Lewis (2013), lowering employment protections are proposed by European policy makers as a remedy to high levels of unemployment and weak economic growth. It is implied that weaker employment protections will decrease the wages of the employees, increases hiring activity, improves flows in the market, which leads to lower unemployment. On the other side, restrictions on dismissal and obligations on severance payments limit the ability of firms to hire more workers and aggravate unemployment (Lazear, 1990; Saint-Paul, 2004).

Therefore, following the ongoing debate on labour market deregulation and corresponding consequences, I provide an empirical analysis on the output and unemployment multipliers of government expenditure by focusing on the transmission of fiscal policy in labour markets with different employment protection levels. The analysis focuses on 11 advanced OECD countries ${ }^{3}$, including Austria, Belgium, Finland, Germany, Ireland, Italy, the Netherlands, Portugal, Spain, the UK and the US and spans quarterly period of 1999-2013.

\footnotetext{
${ }^{3}$ Sample is constrained with the data availability of the fiscal variables. A balanced panel with sufficient amount of observation was obtained for 11 countries listed above. On the other side, countries such as France and Greece are excluded from the sample due to lack of sufficient data for the considered sample period.
} 
Labor market flexibility is proxied by using employment protection legislation (EPL) indicator of OECD database, which refers to the entire set of regulations concerning both firing and hiring decisions, such as dismissal protection, fixed-term employment and temporary agency work. I split my sample into two regimes by estimating a threshold value for EPL index via maximum likelihood approach of Galvao (2006). For identification, I employ the SVAR approach of Blanchard and Perotti (2002) and hence impose restrictions on the contemporaneous structural relationship between the endogenous variables. To estimate the panel structural threshold VAR model, I follow Pesaran and Smith (2005) and use the mean group estimator, which provides a consistent estimate of the mean effects by averaging the impulse responses across countries. Additional to GDP and unemployment responses, I also examine the effects of government expenditure shock on GDP components, private consumption and private investment, as the responses of variables other than GDP are also essential in studying the channels of fiscal policy operation on the labor market (Monacelli et al. 2010).

My main findings are as follows. The estimation results on the panel linear model, in which the whole sample of countries are included, show that fiscal stimulus has positive impact on economic output and there is a significant negative response on unemployment. When I move to the non-linear setting, I find significant differences between flexible and rigid labour markets. The impulse response of GDP to government spending shock is positive and more effective in flexible labour markets, whereas it appears to have less and mostly insignificant impact in the rigid regime. Additionally, government expenditure shock leads to higher overall unemployment in highly regulated countries; whereas the labour market flexibility contributes a decrease in unemployment.

The responses for the GDP components show that the behaviour of private consumption and investment resemble largely the responses of GDP for both of the regimes, whereas it is also observed that the behaviour of private consumption is muted compared to the GDP responses. The response of private consumption to government expenditure shock is positive and more effective in the flexible labour markets than the rigid one as one would expect. Private investment has also positive significant response in both of the regimes, whereas the impact is significantly 
higher in the flexible one; thus consistent with the other results.

To check for the reliability of the results, I do some robustness checks. First, I split the sample exogenously. Instead of applying the threshold estimation, I calculate the country-specific averages of the EPL index and compare them with the sample median of these averages. Second, to filter out the impact of business cycle fluctuations, I exclude the recent recession periods from the sample. As a result of these checks, neither the selection of the samples nor the estimation results do alter.

My empirical results emphasize that fiscal stimulus may not be able to help rigid labour markets in boosting the economic growth and reducing the unemployment rate. As high employment protections in the labour markets affect the unemployment rate negatively by reducing job finding and creation rates, it is suggested that the flexibility of labour markets plays a crucial role in the success of fiscal policies. Therefore, in order to benefit more from fiscal stimulus, further deregulation in the labour markets may be taken as a policy advice for the economies such as, the European periphery, namely Italy, Portugal and Spain, which are subject to strict regulations.

My paper contributes to the existing literature by studying the labour markets in a nonlinear setting. To my best knowledge, this is the first study to analyze the economic impact of fiscal stimulus in different labour markets by examining the advanced OECD countries as a panel. Even though a growing academic literature has analyzed the economic effects of the fiscal stimulus packages, most of these studies have focused on the impact in the US economy, such as Cogan et al. (2010), and none of them has examined the impact in different labour market regimes specifically.

The paper is structured as follows. The next section gives some examples and evidence from the relevant literature and motivation lying behind my research question. The stylized facts are presented in this part while it gives some details on the flexible and the rigid labour market structures. In section 2, data and the variables used in the estimations are presented. Section 3 discusses the methodological issues, by giving details on the estimation methods. The results based on different labour market regimes are introduced in section four. The fifth section 
represents the robustness checks. Finally, the sixth part concludes the study.

\subsection{Empirical literature}

This paper seeks to contribute to the empirical literature studying the dynamics of macroeconomic variables after a government expenditure shock. These effects are mostly analyzed by using vector autoregressive models. The use of VARs has become an attractive tool in macroeconomics after the work of Sims (1980). The ongoing debate on the existing fiscal policy literature that uses VAR approach is the substantial disagreement regarding how one should identify the fiscal policy shock.

Numerous of these studies assume the linearity of the transmission mechanism of shocks and study the effects regardless of the initial conditions of the economy. Within a linear framework, they use different estimation and calibration methods to identify structural fiscal shocks. There are four main approaches used in the identification; the recursive identification scheme ${ }^{4}$, also called as Cholesky ordering (e.g. Fatas and Mihov, 2001; Corsetti and Müller, 2006); nonrecursive structural identification scheme ${ }^{5}$ proposed by Blanchard and Perotti (2002) (e.g. Perotti, 2005; Galí et al., 2007); sign restriction approach ${ }^{6}$ developed by Uhlig (2005) (e.g. Mountford and Uhlig, 2009; Pappa, 2009) and narrative approach ${ }^{7}$ mostly used for the U.S. analysis (e.g. Ramey and Shapiro, 1998; Ramey, 2011).

This paper follows the identification strategy of Blanchard and Perotti (2002) (hereafter BP). In their study, they analyze the dynamic effects of shocks in government spending and taxes on economic activity in the U.S. during the period 1960-97. Their identification scheme relies

\footnotetext{
${ }^{4}$ In this approach, the ordering of the variables determines the identification of the SVAR model. It assumes that the variable in the first order is not affected by any other shock contemporaneously.

${ }^{5}$ Blanchard and Perotti identify the fiscal shocks by imposing contemporaneous restrictions on the reduced form innovations to derive the structural fiscal shocks. They use the restriction that government expenditure does not contemporaneously react to changes in macroeconomic variables to identify fiscal shocks.

${ }^{6}$ Sign Restriction approach puts restrictions on the sign of the impulse responses of the variables.

${ }^{7}$ Narrative approach identifies discretionary policy actions by using the dummy variables constructed for specific historical events. Pappa (2009) uses the robust theoretical sign restriction to analyze the fiscal policy impacts on labour market variables such as employment and real wages.
} 
on institutional information about the tax and transfer systems and the timing of tax collections to identify the elasticities of revenues and expenditures with respect to the economic activity. They show that expansionary government expenditure shocks increase output, while tax shocks have negative effects. They also establish a negative impact on investment spending due to an increase in taxes and government expenditure. Following BP, Perotti (2005) studies the effects of fiscal policy on GDP by including inflation and the ten year nominal interest rate in the SVAR model and imposing additional institutional assumptions on these two variables. He finds that the impact of government expenditure shocks and tax cuts on GDP and its components have got weaker over time and after 1980, the effects become negative, particularly on private investment.

Contributing to the literature that studies the impact of fiscal policy on economic activity using a standard SVAR approach, there are a few recent studies analyzing the unemployment and labour market impact of fiscal policy. Pappa (2009) studies the transmission of fiscal shocks in the labour market in the US. She finds that increases in government consumption and/or investment contemporaneously increase real wages and employment. Monacelli et al.(2010) estimate the effects of fiscal policy on the labour market of the U.S. economy by using a structural VAR model. They confirm the results of Pappa by finding negative significant impact of government spending on unemployment and also significant response of job finding probability and separation rate. Brückner and Pappa (2012) extend the literature by studying the unemployment effects of fiscal policy for a number of OECD countries and find that government spending can raise both employment and unemployment simultaneously by increasing the labour market participation rate.

There are some recent papers studying the influence of the labour market flexibility on unemployment. Turrini (2012) questions the impact of fiscal consolidation on unemployment and job market flows across EU countries. By using an augmented AR2 model, he shows that the fiscal policy shocks on job separation rates is much stronger in the low regulated labour markets, while for more rigid labour markets there is a stronger reduction in the rate at which new jobs are created. This result is accompanied with longer average duration of and stronger impact on long-run unemployment in the rigid labour markets. Another recent study by Agnello et al. 
(2014) investigate whether labour market flexibility promotes a reduction in unemployment and fiscal consolidation affects unemployment. They find that increase in the labour market flexibility decreases the youth unemployment but long-term unemployment does not seem to respond, whereas only tax-driven consolidations lead to higher unemployment rate. Even though these two studies investigate some research on the policy implications of labour market flexibility, they focus on the link between unemployment and the degree of tightness in the markets, not on the fiscal stimulus impacts.

Beside from the aforementioned studies based on the linear framework, a large literature focus on the non-linearity of fiscal policy. Perotti (1999) studies the effects of government spending shock on private consumption and concludes that the impact is positive during normal times and negative in bad. He describes normal times as the periods with low debt-to-GDP or deficit-toGDP ratios. Auerbach and Gorodnichenko (2012) argue that the effects of fiscal policies may vary over the business cycle. By using regime-switching models, they find that the spending multiplier is bigger in recessions than expansions. Fazzari et al. (2013) investigate the statedependent effects of fiscal policy and find that the the effect of government spending shock on output is larger and more persistent when the economy is far away from full capacity than close to it.

Large amount of studies emphasizing the non-linear evidence on the fiscal policy effects on economic outcome show that the linear framework is not sufficient to explain these fiscal effects and may lead to misleading findings (Baum and Koester, 2011). In the VAR literature, there are different methods to model the non-linearity, such as smooth transition regression and Markov switching models (e.g. Arin and Spagnolo, 2011; Auerbach and Gorodnichenko, 2012). Contributing to the literature, I use a threshold estimation method for sample splitting and adopt a non-linear SVAR approach. To my knowledge, this is the first study to consider the statedependent effects of fiscal policy depending on the labor market structure for a panel of advanced countries. None of the aforementioned studies compare and contrast the effectiveness of fiscal stimulus in flexible and rigid labour markets. 


\subsection{Stylized facts on labour market measures}

When we have a closer look at the budget decomposition of the fiscal packages, it can be observed that the advanced European economies strongly focused on labour market measures to cushion the fall in economic output and employment (Faia et al., 2013). Figure 1 shows the labour market share of the total stimulus packages among G20 countries. It can be observed that the advanced economies such as Italy, Germany, the UK and the US spent around 10 per cent or even more of their total fiscal stimulus on labour market measures (IILS, 2011). This measure includes public spending such as expenditures on unemployment insurance contribution, higher pensions, regional job support initiatives, training opportunities, unemployment protection and support young people in access to employment and the return to pension fund (Zhang et al., 2011). Actually, this measure does not even capture the expenditure on pre-existing measures like the short-time work arrangement, such as German Kurzarbeit and the Italian Cassa Integrazione, which is seen as one of the key strategy responses to the current economic crisis and corresponds to around 5 to 6 billion Euros in the countries that made use of this scheme, such as Germany and Italy (Walz et al., 2012; Boeri and Brücker, 2011). ${ }^{8}$ Thus, the reported ratio masks the true size of the labour market measures in these economies. The actual measure is then even higher than the ratios reported. Comparing the advanced economies with developing and emerging markets, it is observed that the budget spent for labour market measures in the advanced economies is considerably higher (IILS, 2011). As advanced countries have found it crucial to intervene in their labour markets in face of the financial crisis, it is relevant and important to study how these economies are affected from fiscal stimulus and whether the stimulus impact differs depending on different labour market structures.

The aim of the study is to investigate whether flexible and rigid labour markets react differently to fiscal innovations. To motivate this objective, I show some evidence from my dataset in the following. Figure 2 presents two simple scatter plots that link government spending and GDP growth in Portugal, as the extreme rigid labour market, and the UK, as one of the most

\footnotetext{
${ }^{8}$ The expenditure donated to short time work arrangements in Germany and Italy corresponds between .1 and .3 percent of their GDP (Boeri and Brücker, 2011).
} 
Figure 1: Labour market measures as a share of total stimulus (as a \% of total fiscal package)

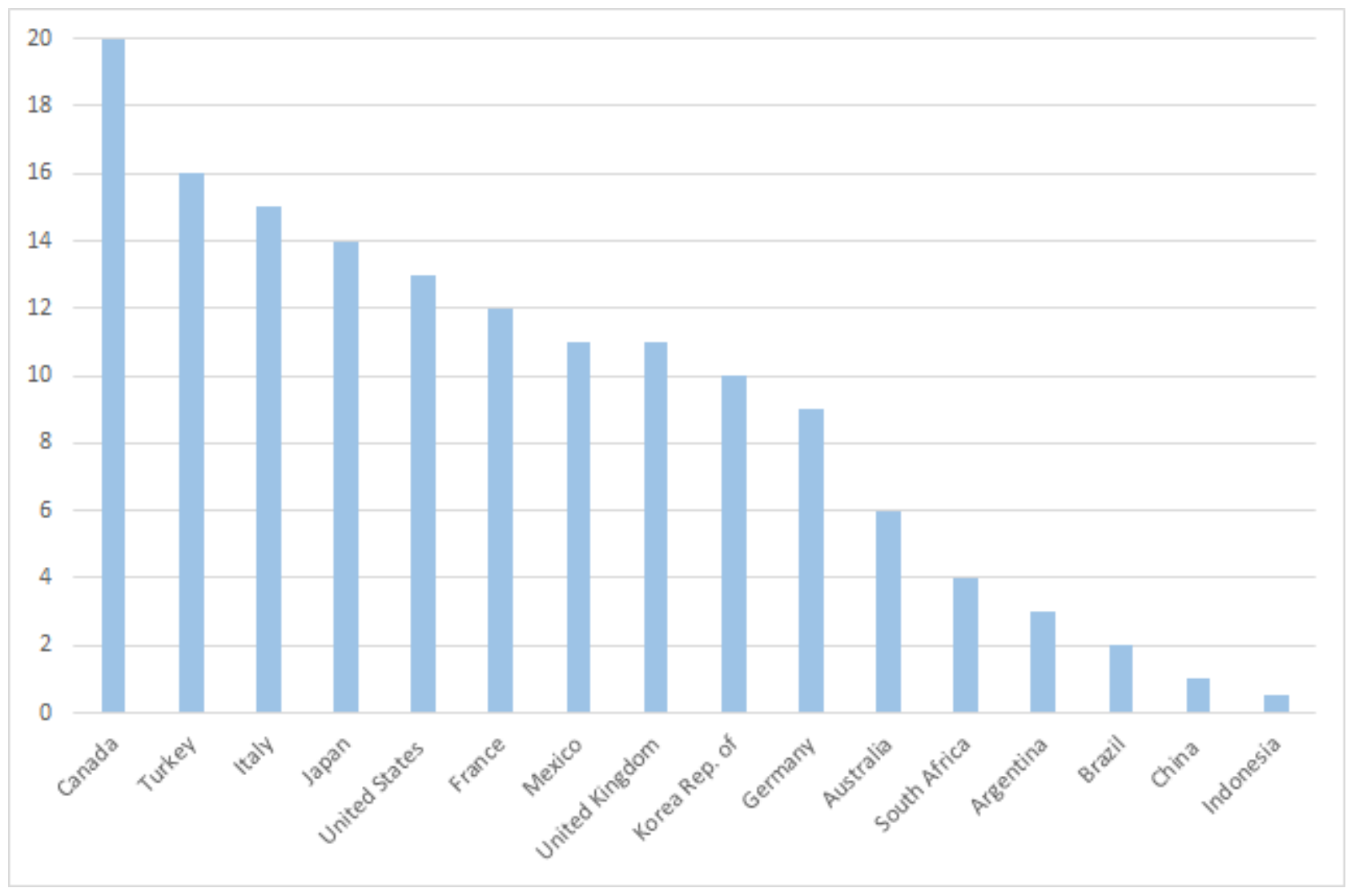

Source: IILS 2011.

flexible labour markets among OECD countries. Both variables are in real and per capita terms. It is observed that the plot for the UK has a steeper slope compared to the Portuguese case. Thus, the link between expenditure and GDP is much stronger in the UK than Portugal. One possible explanation is a more effective fiscal policy impact in the more flexible labour market. ${ }^{9}$ In rigid labour markets, such as Portugal and the continental European Economies (especially in the south), high employment protection in the market put strict restrictions on the working contracts that disables the employers to respond and adopt to the changes and the sudden economic shocks. As the labour flow in these markets are slow due to heavy regulations, it is costly to hire new

\footnotetext{
${ }^{9}$ One may also plot the scatters for other sample countries, such as Germany and the US, the plot remains steeper for the flexible economy consistently and statistically significantly.
} 
employees and the matching efficiency is low in these labour market. Thus, facing with heavy regulations in the rigid labour markets, employers find it less profitable to react to fiscal stimuli. On the other side, in flexible labour markets, such as the UK and the US, the bargaining power and hiring/firing costs are relatively low. The workers are subject to much fewer regulations compared to most of the European countries. The job creation rate is high and the labour flows easily in the market. Therefore, the markets may react to the shocks more effectively and may end up with higher fiscal stimulus impacts compared to the highly regulated markets.

Figure 2: Scatter plots

(a) Portugal

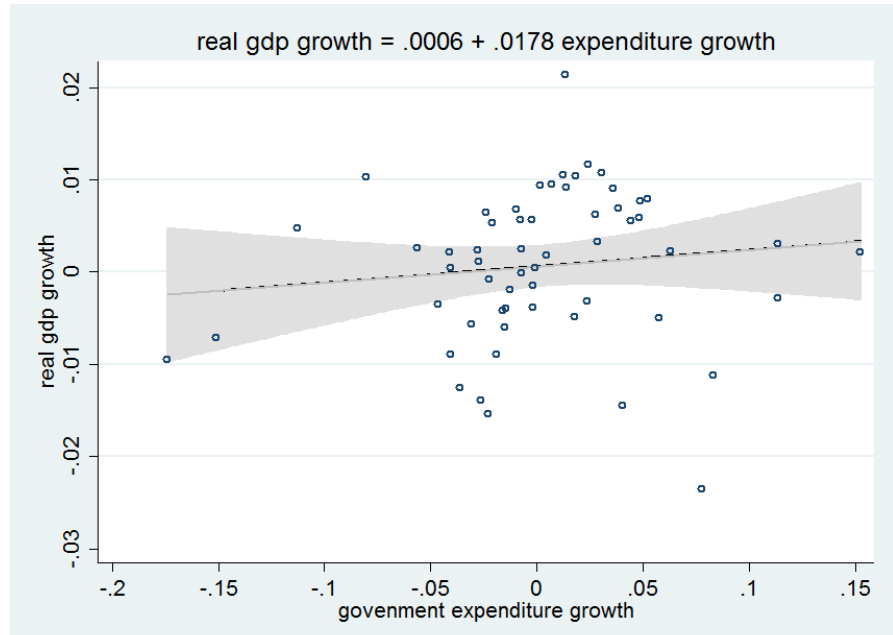

(b) UK

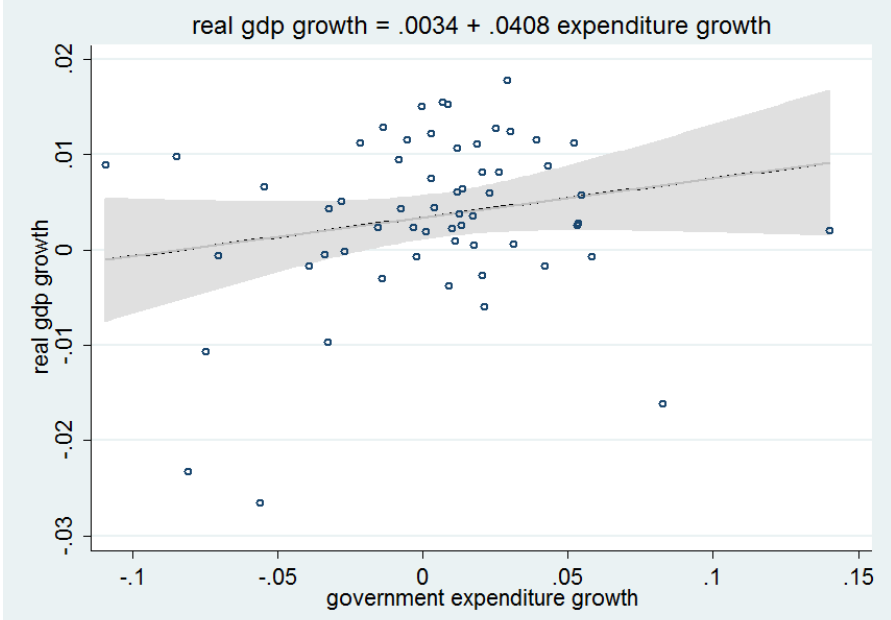

Source:Author's calculation. 


\section{Data}

Data availability in fiscal policy papers is a big hurdle. Using quarterly data is a crucial criteria in order to get precise estimates and essential for the validity of the identification of the structural VAR model. ${ }^{10}$ As data interpolated from annual data may also lead to spurious estimation results (Ilzetzki et al., 2013), I use quarterly data collected at quarterly frequency for my analysis.

The analysis focuses on 11 advanced OECD economies; Austria, Belgium, Finland, Germany, Ireland, Italy, the Netherlands, Portugal, Spain, the UK and the US. I compile the quarterly data spanning the 1999-2013 period by using different data sets, such as Eurostat, OECD and Federal Reserve Economic Data (FRED). More details on the data sources are given in the Appendix.

I include four macroeconomic variables in my benchmark structural VAR model; general government expenditure, general government revenue, real GDP and unemployment rate. Except for the unemployment rate, all series are in real and per capita terms. As my data showed strong seasonal patterns, I use X-12 algorithm to seasonally adjust the variables in levels. I apply the logarithm to these series and take the first differences in order to achieve stationarity. After detrending the data, I employ the standard uni-root methodology by applying the Augmented Dickey Fuller (ADF) test. The values report that the series are stationary by rejecting the null hypothesis of the existence of a unit root at the $99 \%$ confidence level for growth series.

Additionally, to study the impacts on GDP components, I collect the data for private consumption and investment and set a 5 variable structural VAR model. Data is obtained from OECD Main Economic Indicators Original Release Data and Revisions Database. These series are in real terms, seasonally adjusted and non-interpolated.

In my non-linear specification, the employment protection legislation (EPL) index is used as a proxy for labour market flexibility. The index is obtained from OECD Employment Database. ${ }^{11}$

\footnotetext{
${ }^{10}$ This condition comes from the assumption of SVAR, which requires that fiscal policymakers need at least one quarter to respond to the new economic data with discretionary policy (Blanchard and Perotti 2002, Ilzetzki et al. 2013).

${ }^{11}$ There are some recent studies in the literature that use the OECD index in their analysis to study the flexibility in
} 
EPL refers to the set of regulations governing the initiation and termination of employment contracts, also known as job security rules (OECD, 2004; Betcherman, 2013). It shows the level of labour market protection that is implied by the national legislation. The index is compiled from 21 sub-components including three aspects of employment protection: individual dismissal of workers with regular contracts, additional provisions for collective dismissals and the regulation of temporary contracts. These are the two summary indicators of EPL, that are key for policy analysis, concerning the regulations governing individual and collective dismissals of workers with permanent, open-ended contracts and the rules the temporary contracts.

The regular contract regulations incorporate the dismissal protections such as notification and consultation requirements, notice periods and severance pay, difficulty of dismissal and the consequences for the employer in case of an unfair dismissal, such as compensation and reinstatement. It also covers the regulations governing hiring of workers on fixed-term contracts, such as allowance of renewal and cumulative duration. On the other side, the regulations of temporary contracts quantify such rules for the employment of temporary work agency (OECD, 2013). ${ }^{12}$

In my study, I use the composite index of employment protection rules based on both of the summary indicators, which is obtained as a weighted average of the indices for both regular and temporary contracts. ${ }^{13}$ The scale of the index is from zero to six, the higher score representing the more regulated markets. Even though the values on regular contracts are assumed to be the core component of the overall index by OECD sources (OECD, 2013), taking into account the temporary contract index is also crucial. When the index is closely examined, it can be observed that the most of the changes in the composite index is a source of the variation in the temporary

the labour market, such as Tridico (2012) and Olney (2013).This indicator is accepted as an objective and consistent estimate of employment protection legislation. The changes in its level are assumed to be a sign for the changes in the legislation and policies.

${ }^{12}$ For more details on the components of the index and its calculation method, see the methodology section of OECD indicators of employment protection web-page at www.oecd.org/employment/protection.

${ }^{13}$ OECD reports an overall summary index of the strictness of EPL by obtaining a weighted average of employment protection for regular contracts, including additional provisions for collective dismissals (EPRC), and the synthetic indicator on regulation for temporary workers (EPT). The weights on EPRC is $7 / 12$, whereas it is $5 / 12$ for EPT. 
contract part especially after the recent labour market reforms in the advanced economies.

Figure 3 plots the country specific employment protection index over the sample period. As can be seen, Portugal is the most restrictive labour market in the sample with application of many strict rules and regulations, while the US is the most flexible one with the weakest set of legislation. Even though Portugal undertook some actions to relax its regulation rules since the onset of the recent economic crisis, it still stays among the extreme rigid countries with the other Southern European economies (Spain and Italy). On the other side, the index is low among the Anglo-Saxon Economies; Ireland, the UK and the US. As it stays constant for the US all along the period, for most of the other countries, the index has changed significantly in the last decade. The change is mostly attributed to the regulations affecting temporary contracts, such as in Germany.

The EPL index plot in Figure 3 confirms Nickell's (1997) argument on the distribution of the rigid and flexible labour markets geographically. As he reports, traditionally, Anglo-Saxon economies, such as Ireland, the UK and the US, have more flexible labour markets than the European countries. Moreover, if we make a comparison within Europe, the southern European countries, Italy, Portugal and Spain, have the toughest restrictions and regulations. And the markets get more flexible as one moves further to the north, such as Finland and the Netherlands.

\section{Methodological issues}

This section outlines the estimation methodology used. To address the identification problem, I employ the SVAR approach as in Blanchard and Perotti (2002). My model is presented as follows:

$$
Y_{i t}=\Phi_{1}(L) Y_{i t}+\Phi_{2}(L) Y_{i t} I\left[\gamma_{i t-d} \leq \hat{\gamma}\right]+u_{i t}
$$

where $Y_{i t}=\left[\right.$ expenditure $_{i t}$, revenue $_{i t}, G D P_{i t}$, unemployment $\left._{i t}\right]$, $\gamma_{i t-d}:$ threshold series, where $\mathrm{d}$ is the delay parameter, 
Figure 3: Employment Protection index

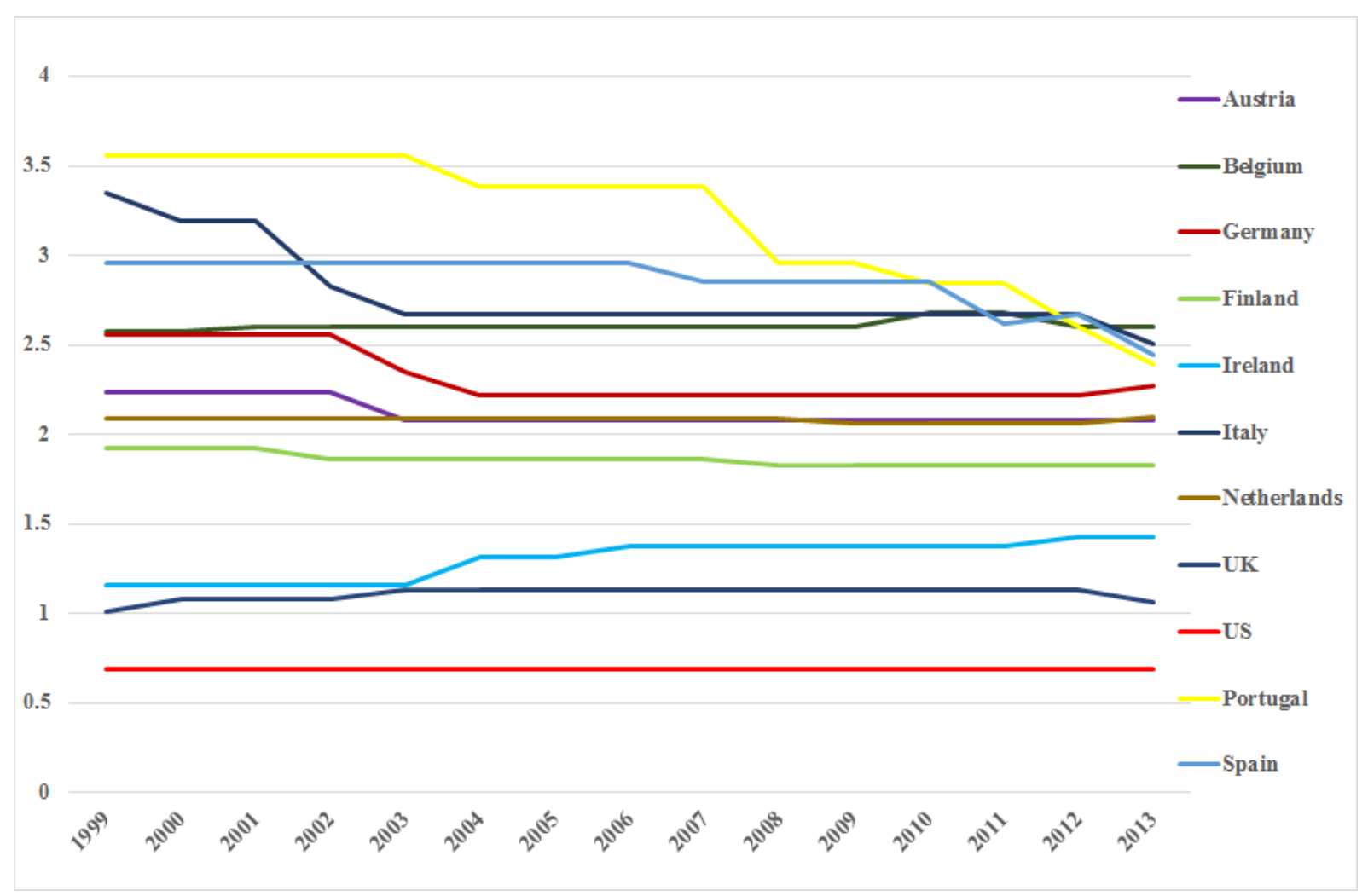

Source:Authors's calculation based on OECD Employment Protection Legislation Index

I(.) : indicator function,

$\hat{\gamma}$ : estimated threshold value,

$\Phi_{1}$ and $\Phi_{2}$ : coefficient matrices.

In my empirical analysis, first I test if the system is indeed non-linear. Once the non-linearity of the system is verified, I estimate the threshold value for the employment protection index, which splits my sample into two regimes as flexible and rigid. After the sample split, I calculate country specific structural VARs, by identifying the structural shocks. And finally, by averaging the country specific impulse responses over regimes, I find two sets of the impulse responses. Additionally, I accumulate the regime specific impulse responses to show the differ- 
ences between two regimes more efficiently and support my findings based on non-cumulative impulse responses. In the following parts, I explain my empirical approach by giving details on the estimation of threshold, application of structural VAR, identification of the structural shocks, considered elasticities, and panel VAR estimation technique.

\subsection{Threshold estimation}

Before estimating the non-linear model, I test for the presence of a threshold effect by setting the null hypothesis of a linear VAR against the nonlinear alternative. So under the null, there is no threshold and the model reduces to a linear VAR. In order to test for non-linearity, I use the test statistics developed by Tsay $(1989,1998)$. Once the null of linearity is rejected, it implies that my model is nonlinear and the threshold effect is statistically significant.

After finding an evidence for the threshold effect, the next step is the estimation of the threshold. I determine the threshold endogenously by using a grid search over all possible values of the threshold variable. First I identify the series representing the threshold variable that is restricted to a bounded set such as $S=(\underline{\gamma}, \bar{\gamma})$, where $S$ is the interval of the full range of threshold values. The threshold methodology suggests that in order to assure sufficient number of observations, which is required for obtaining enough degrees of freedom for the estimation of the parameters, the interval S should be trimmed from its upper and lower bounds. I trim the threshold variable at $15 \%$, thus the model is estimated for possible values of the threshold variable over a grid, where the lower bound is the 0.15 th percentile and the upper is the 0.85 th percentile of $\gamma_{i t-d}{ }^{14}$

In order to determine the threshold estimator, I apply the maximum likelihood approach by following Galvao (2006). After estimating the model for all possible values of $\gamma$ over a grid on the interval, $\left[\gamma_{l}, \gamma_{u}\right]$, the residuals , $\hat{u}_{i t}$, are obtained based on these estimates. Using the residuals, the covariance matrix is computed as $\hat{\Sigma}(\gamma)=\left(\hat{u}^{\prime} \hat{u}\right) / T$, where $\mathrm{T}$ is the dimension of the time

\footnotetext{
${ }^{14} \mathrm{~A}$ trimming value of $15 \%$ is used commonly in the literature (Andrews, 1993; Galvao, 2006). There are also some studies, such as Clements and Galvão (2004), using the trimming percentage of $10 \%$. In my analysis, I trim the threshold variable at $15 \%$ to ensure enough degrees of freedom in both regimes. Additionally, I also tried $10 \%$ trimming value and it did not alter my threshold estimation.
} 
series. Thus, the maximum likelihood (ML) estimator is obtained by:

$$
\hat{\gamma}(d)=\min _{\substack{\gamma_{l} \leq \gamma \leq \gamma_{u} \\ d_{l} \leq d \leq d_{u}}} \log (\operatorname{det}(\hat{\Sigma}(\gamma))
$$

At this step, the assumption on the structure of the variance covariance matrix plays a crucial role. The above presented reduced form VAR (Equation 1) and maximum likelihood estimator (Equation 2) are built by assuming that variance covariance matrices are assumed to be same for each regime. Nevertheless, this assumption may not hold when working on a macroeconomic model with regime dependent volatility (Galvao, 2006). Thus, the estimator should be modified to allow for regime switching variances. I assume that errors and thus contemporaneous shocks behave differently in each of these regimes. Under heterogeneity assumption across two regimes, the system of equations to be estimated for the reduced-form VAR with one threshold is given as follows:

$$
Y_{i t}=\Phi_{1}(L) Y_{i t}+u_{1, i t}+\left[\Phi_{2}(L) Y_{i t}+u_{2, i t}\right] I\left[\gamma_{i t-d} \leq \hat{\gamma}\right]
$$

In order to attain a consistent maximum likelihood estimator, I use a modified objective function following Galvao (2006). The optimization problem considering two regimes and the changes in the regime dependent variances can be written as the following:

$$
(\hat{\gamma}, \hat{d})=\min _{\substack{\gamma_{l} \leq \gamma \leq \gamma_{u} \\ d_{l} \leq d \leq d_{u}}}\left[\frac{T_{1}}{2} \log \left(\left|\Sigma_{u}^{1}\right|\right)+\frac{T_{2}}{2} \log \left(\left|\Sigma_{u}^{2}\right|\right)\right]
$$

where $\hat{\Sigma}_{u}^{1}=\sum_{t=1}^{T_{1}} \hat{u}_{t}^{1} \hat{u}_{t}^{\prime 1}$ and $\hat{\Sigma}_{u}^{2}=\sum_{t=1}^{T_{2}} \hat{u}_{t}^{2} \hat{u}_{t}^{\prime 2}$ are maximum likelihood estimators for the covariance matrices. Here, $T_{1}$ and $T_{2}$ are sample sizes for regime 1 and 2 , respectively, where $T_{1}+T_{2}=T$ and $T$ is the total sample size.

Therefore, the estimated threshold, $\hat{\gamma}$, is the one that minimizes the objective function and the sum of squared residuals over the trimmed series of the threshold variable. And $\hat{d}$ is delay 
parameter, which is also determined by the test statistics and implies the lag for the threshold variable.

\subsection{Structural VAR}

After the sample splitting, I calculate the country specific impulse responses based on the structural VAR approach of Blanchard and Perotti (2002), which is a seminal paper for fiscal policy applications in structural VAR literature. There is a basic assumption behind their approach, which is about the time requirement of the fiscal policy in order to respond to any change in the economic system or news about the state of the economy. The methodology is based on the assumption that discretionary policy does not respond to output within a quarter. They argue that governments are not be able to respond to changes of the macroeconomic environment within a quarter as fiscal policy making is a long process involving many agents. Therefore, the fiscal policy changes appearing in a given quarter are defined as structural fiscal policy shocks (Wolff et al., 2006).

\subsubsection{Identification}

In the following, I explain the structure of the SVAR model by following the AB-model of Amisano and Gianninni (1997). The reduced VAR equation (equation 3) can be written in a form of a piecewise linear VAR:

$$
Y_{i t}= \begin{cases}\Phi^{1}(L) Y_{i t-1}+u_{1, i t}, & \text { if } \gamma_{i t-d} \leq \hat{\gamma} \\ \Phi^{2}(L) Y_{i t-1}+u_{2, i t}, & \text { if } \gamma_{i t-d}>\hat{\gamma}\end{cases}
$$

I obtain the structural form of threshold VAR by pre-multiplying each of these two linear VARs by the matrix that describes the instantaneous relation between variables, $A$. The general form of the model can be given as the following: 


$$
A Y_{i t}=A \Phi(L) Y_{i t-1}+A u_{i t}=A \Phi(L) Y_{i t-1}+B \epsilon_{i t}
$$

By solving the latter equation of $Y_{i t}$, I find the structural moving-average representation of the model, whose coefficients are the structural impulse response functions:

$$
Y_{i t}=[I-A \Phi(L) L]^{-1} A^{-1} B \epsilon_{i t}
$$

And finally, I obtain the relation between the reduced form innovations $u_{i t}$ and the structural shocks, $\epsilon_{i t}$; which is the main assumption of AB-model of Amisano and Giannini (1997):

$$
A u_{i t}=B \epsilon_{i t}
$$

where $A$ and $B$ present the instantaneous relationship between the variables and the linear link between reduced form residuals and structural shocks.

\subsubsection{Estimated elasticities}

In my benchmark specification, $Y_{i t}$ consists of 4 macroeconomic variables: real government spending growth per capita, real government revenue growth per capita, real GDP growth per capita, and the unemployment rate. Following Monacelli et al. (2010), the variables enter in this order. Building on Blanchard and Perotti (2002), I identify the structural shocks by imposing restrictions on the matrices $A$ and $B$. I assume that the $A$ and $B$ vary across countries. In my SVAR setting, $u_{t}$ is the vector of reduced-form error terms for the macroeconomic variables in each of the countries and $\epsilon_{t}$ represents the structural shocks corresponding the given variables with $\operatorname{Cov}\left(\epsilon_{t}\right)=I_{4}$. The AB representation of my structural VAR model is given as follows:

$$
\left[\begin{array}{cccc}
1 & 0 & \alpha_{g y} & \alpha_{g u} \\
0 & 1 & \alpha_{t y} & \alpha_{t u} \\
\alpha_{31} & \alpha_{32} & 1 & 0 \\
\alpha_{41} & \alpha_{42} & \alpha_{43} & 1
\end{array}\right]\left[\begin{array}{l}
u_{g t} \\
u_{t t} \\
u_{y t} \\
u_{u t}
\end{array}\right]=\left[\begin{array}{cccc}
\beta_{11} & 0 & 0 & 0 \\
\beta_{21} & \beta_{22} & 0 & 0 \\
0 & 0 & \beta_{33} & 0 \\
0 & 0 & 0 & \beta_{44}
\end{array}\right]\left[\begin{array}{c}
\epsilon_{g t} \\
\epsilon_{t t} \\
\epsilon_{y t} \\
\epsilon_{u t}
\end{array}\right]
$$


Some identification assumptions are needed in order to estimate the coefficients in the matrices A and B. Some parameters are given exogenously and some are free. In line with Blanchard and Perotti (2002), I set $\alpha_{g y}=\alpha_{g u}=0$. Therefore, it is assumed that there is not any automatic feedback from economic activity and unemployment to government expenditure. In order to set the other elasticities, I use the information from Girouard and Andre (2005), which provides the available information on a country-by-country basis. Tax and the unemployment elasticities differ across countries. Girouard and Andre (2005) document the expenditure and revenue elasticities with respect to output gap for OECD countries. Following Tagkalakis (2013), I calculate the revenue elasticity of output by average weighting the output elasticity of corporate income tax, personal income tax, social security contributions and corporate income tax depending on the shares of the tax categories. I find the proxy for unemployment elasticities to revenue by multiplying the output elasticity of revenues with the inverse of the elasticity of unemployment with respect to the output gap, which is reported in Girouard and Andre (2005), as done in Tagkalakis (2013). Following Blanchard and Perotti (2002), I set $\beta_{12}=0$ and estimate $\beta_{21}$. Therefore, in total, I have six free parameters to be estimated. ${ }^{15}$ The calculated exogenous elasticities are listed in Table1. After estimating the reduced form of VAR and defining the restrictions, I use the reduced form residuals $u_{i t}$ in order to estimate the free parameters in A and B matrices.

Additional to the benchmark model, I run a 5 variable structural VAR model, in which each component of GDP, namely private consumption and investment, is added in turn to the benchmark specification. The elasticities of the fiscal variables with respect to private consumption and investment are equal to the reported calculated elasticities with respect to real GDP weighted by the each components ' GDP share in the sum of both. The shares for each of the countries are reported in Table 2.

\footnotetext{
${ }^{15} 2 n^{2}-n(n+1) / 2$ gives the number of free parameters in the system.
} 
Table 1: Exogenous Elasticities

\begin{tabular}{ccc}
\hline \hline Country & Revenue elasticity to output & Unemployment elasticity to revenue \\
\hline Austria & 0.86 & -0.26 \\
Belgium & 0.85 & -0.26 \\
Finland & 0.80 & -0.14 \\
Germany & 0.86 & -0.17 \\
Ireland & 0.92 & -0.17 \\
Italy & 0.93 & -0.29 \\
Netherlands & 0.84 & -0.11 \\
Portugal & 0.88 & -0.27 \\
Spain & 0.87 & -0.27 \\
UK & 0.85 & -0.16 \\
US & 0.87 & -0.16 \\
\hline
\end{tabular}

Notes: Authors' calculations based on Girouard and Andre (2005) and Tagkalakis (2013).

\subsection{Panel VAR estimation}

To estimate panel structural threshold VAR, I use group mean estimator proposed by Pesaran and Smith (1995), which suggests that the coefficients vary across countries, thus individual country equations should be estimated separately. The structural VAR estimation is done country by country and by averaging the country-specific impulse response point estimates. Instead of pooling this method is preferred since the each country has a different structure. As suggested in Pesaran and Smith (1995), the averages of estimated parameters and standard errors are estimated explicitly. The mean group coefficients are compiled as:

$$
\hat{a}=\sum_{i=1}^{N} \frac{a_{i j}}{N}
$$


Table 2: Shares of private consumption and investment

\begin{tabular}{ccc}
\hline \hline Country & Share of private consumption & Share of private investment \\
\hline Austria & 0.70 & 0.30 \\
Belgium & 0.70 & 0.30 \\
Finland & 0.69 & 0.31 \\
Germany & 0.74 & 0.26 \\
Ireland & 0.69 & 0.31 \\
Italy & 0.74 & 0.26 \\
Netherlands & 0.69 & 0.31 \\
Portugal & 0.75 & 0.25 \\
Spain & 0.70 & 0.30 \\
UK & 0.79 & 0.21 \\
US & 0.76 & 0.24 \\
\hline
\end{tabular}

Notes: Authors' calculations based on OECD Main Economic Indicators Original Release Data and Revisions Database.

where $a$ denotes the country specific coefficients, $N$ represents the number of countries in each regime, $i$ and $j$ stands for the indices of the countries and variables, respectively.

\section{Results}

For my empirical analysis, I split the observations into different regimes based on the threshold estimation of EPL index. As a result of the test for non-linearity in the data by following the multivariate Tsay (1998) procedure, the linearity is strongly rejected with p-value of 0.000 . The optimal lag in the threshold variable is determined as two. In order to determine the lag length in the VAR system, I conduct various model selection tests. The optimal number of lags differ across different countries and specification tests. For simplicity, I set the lag orders to two, which 
is found as the optimal lag for most of the countries depending on at least one lag selection test. ${ }^{16}$

In the following subsections, I present and discuss the estimation results based on the impulse response analysis. First, I start with the results for the linear model in which there is no sample switch, then I present the flexible and rigid labour market results, respectively. And finally, I compare them.

\subsection{Linear impulse responses}

As my benchmark model, I present the results for the panel VAR estimation without considering the structure of the labour markets. The countries in the sample are Austria, Belgium, Finland, Germany, Ireland, Italy, the Netherlands, Portugal, the UK and the US. Since the aim of the paper is to analyze the impact of fiscal stimulus on GDP and unemployment, I show and focus on the discussion on the responses of these variables to expenditure shock. Figure 4 presents the responses of output and unemployment to a government expenditure shock of 1 percentage point (p.p.) of GDP.

The upper panel shows that the initial response of GDP to government expenditure shock is estimated at 0.05 p.p., then it increases to 0.09 p.p. at the second quarter and gradually declines afterwards. The response is found to be statistically significant until the end of the fifth quarter. It is observed that the government spending shock stimulates output during these periods. The cumulative response of output also confirms this stimulation (Figure 5). The cumulative impact increases up to 0.2 p.p. at the fifth quarter.

The lower panel of the figure 4 shows the response of unemployment to the government expenditure shock. This response is also statistically different from zero for most of the time horizon considered. Unemployment falls on impact initially by 0.05 p.p. and continues to decline till the eighth quarter to around 0.1 p.p.. Even though it gradually increases again, the initial impact of 0.05 p.p. is still preserved in the long-run. Thus, the decreases in response

\footnotetext{
${ }^{16}$ The lag length is selected based on non-autocorrelation and the results of the paper are robust to choosing any alternative number of lags from 1 to 4 . Thus, choosing a lag other than two does not alter my main results.
} 
of unemployment stays persistence all along the considered time horizon. This negative impact indicates that government spending shock decreases the overall unemployment through possible job creation ability and/or labour flows existing in the market of the sample countries when taken into account as a whole group.

Figure 4: Linear impulse responses
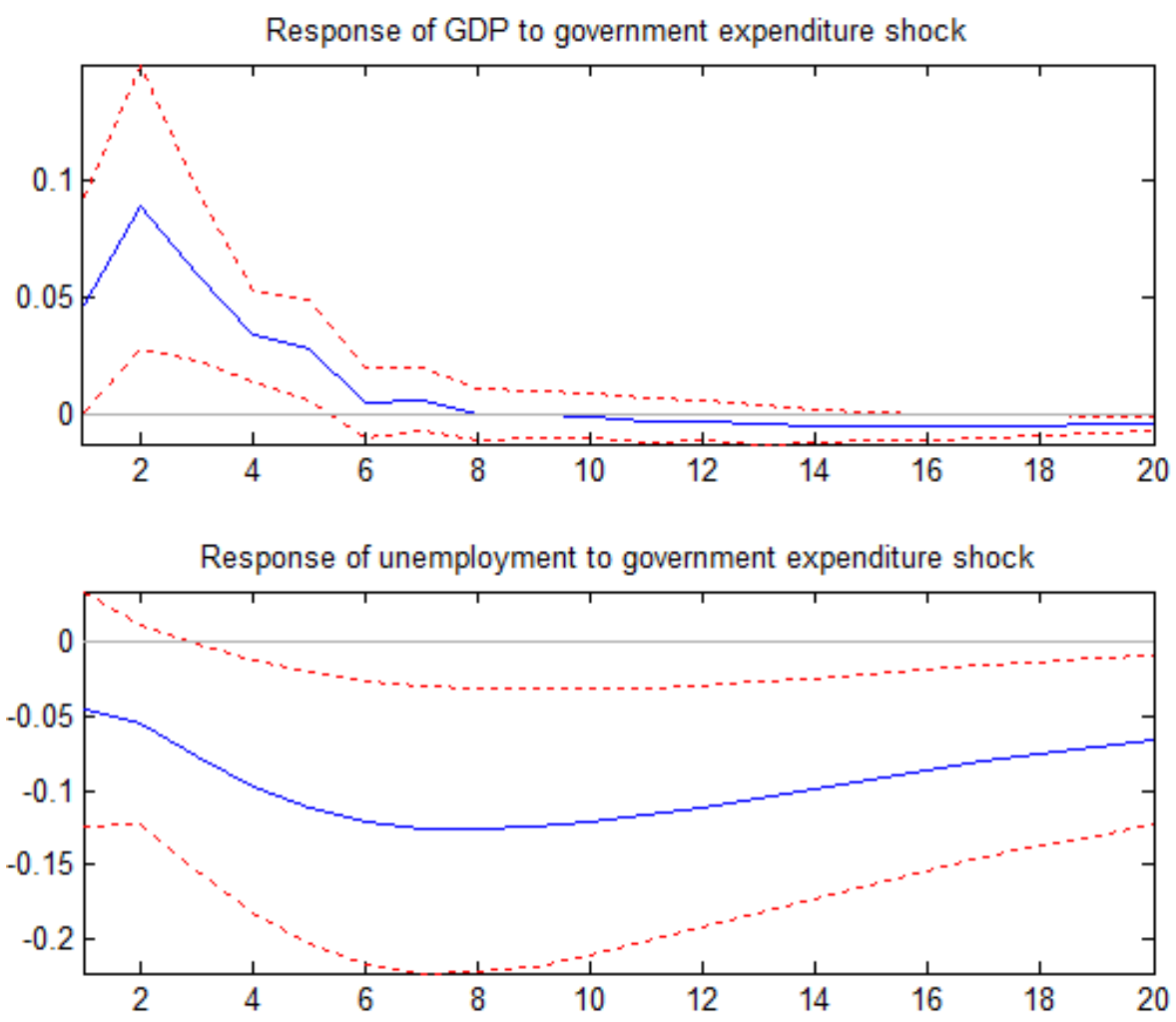

As the next step, I split my sample by using the threshold value estimated for the labour market flexibility indicator, namely EPL index. Figure 6 plots the threshold value which is around 1.93 with country indices. As observed, there are 4 countries in flexible labour market regime. These are Finland, Ireland, the UK and the US. And the rigid regime consists of seven countries, composed of the central and southern European countries, Austria, Belgium, Germany, Italy, the Netherlands, Portugal and Spain. This sub-sampling is consistent with the grouping of rigid and flexible labour markets in the existing literature, e.g. Nickell (1997). 
Figure 5: Linear cumulative impulse response

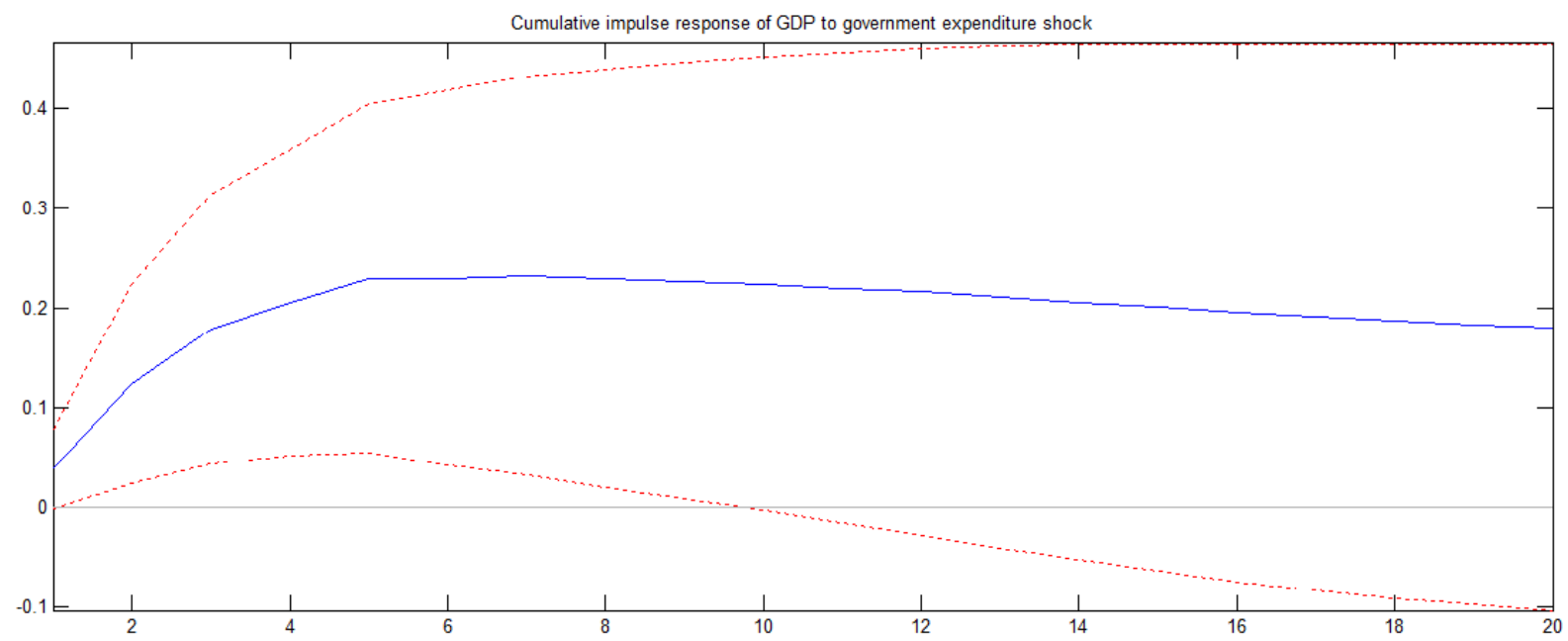

\subsection{Flexible market impulse responses}

Figure 7 shows the impulse responses of output and unemployment for the flexible labour markets. It can be observed that the real GDP response to a fiscal spending shock is positive, much larger and more persistent compared to the linear case. This result implies that the linear model underestimates the impact of government expenditure activity on the economic output. The impact response of GDP is estimated around 0.22 p.p.; it gradually reverts back afterward. This positive response is statistically significant for most of the considered periods.

Consistent with the linear model results, the response of unemployment to government expenditure shock is negative. The unemployment rate falls on impact by about 0.13 p.p. and by 0.29 p.p. six quarters after the shock. The response stays persistent all along the considered time horizon. Therefore, fiscal stimulus seems to stimulate the employment rate in the flexible economies, which may be explained by increase in the job finding rates of the unemployed individuals. Having flexible employment legislation on hirings and firings lower the cost of the employers, which gives them more motivation to hire more workers. By this way, there appears a channel to create new jobs in the economy. Thus, the flexibility of the labour market helps itself to react to the fiscal stimuli. 
Figure 6: EPL index with threshold estimate at 1.93



Source: Authors's calculation from OECD Employment Protection Legislation Index

\subsection{Rigid market impulse responses}

For rigid labour markets, the impulse responses of output and unemployment to government spending shock are shown in Figure 8. The real GDP response to expenditure shock reaches to $0.04 \%$ at the third quarter. Compared to the flexible labour market case, this response is much lower, less persistent and additionally, not that different from zero for most of the time horizon considered. On the lower panel, it is observed that opposed to the flexible labour market finding, unemployment responses positively to $1 \%$ shock to government spending. The initial increase is $0.039 \%$ and the response reaches to $0.06 \%$ at the eighth quarter, at which point it becomes marginally significant. In the long run, the positive impact on unemployment decreases only slightly and stays positive at around $0.05 \%$. Increase in the unemployment rate in these markets 
Figure 7: Flexible market impulse responses
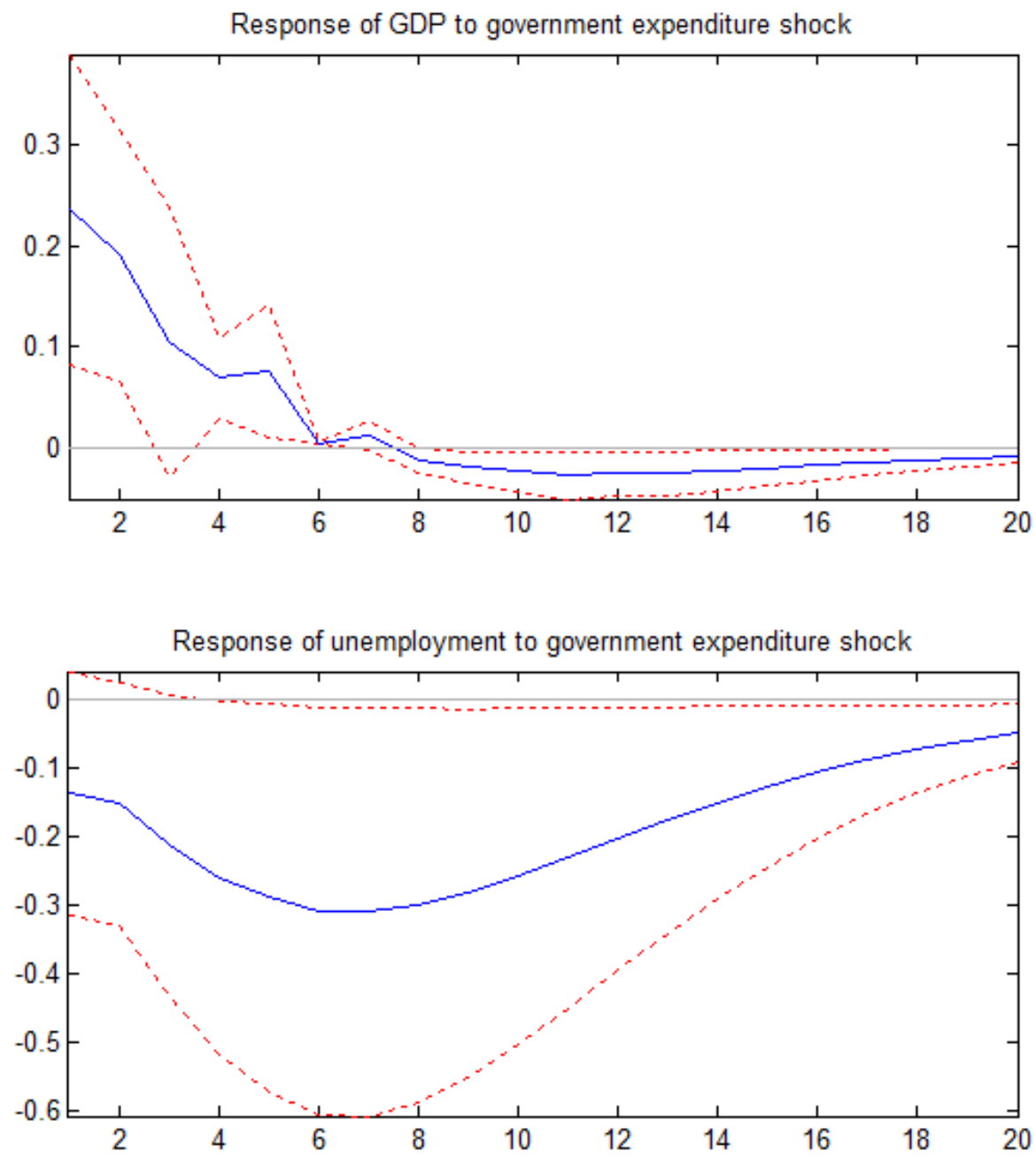

can be explained by existing low job creation rate and high job destruction. Government expenditure shocks trigger a stronger decrease in the new job creation rate, which leads to increase in the overall unemployment in these markets.

As the high regulations on the working contracts protect the employed workers to keep their jobs, they do not allow the employees to fire them. On the other side, these restrictions increase the bargaining power of the employed workers and the costs, such as reservation wages, in the labour market. The burden of the higher costs give disincentive to the employees to hire 
new workers and ability of employment adjustment in the market decreases, which results in higher unemployment in the market. This result is consistent with some existing studies, such as Djankov et al. (2004) and Bernal-Verdugo et al. (2012), which also claim that more rigid labour market regulations are associated with high unemployment due to the high cost of firing and hiring, high job destruction and low job creation rates. Highly regulated and tight employment laws are associated with a lower probability of finding a job for the unemployment individuals (Gomez-Salvador et al., 2004). Thus, the unemployment response for the rigid labour market emphasizes the negative impact of strict employment protection legislation on the labour force participation rate in the market.

Figure 8: Rigid market impulse responses
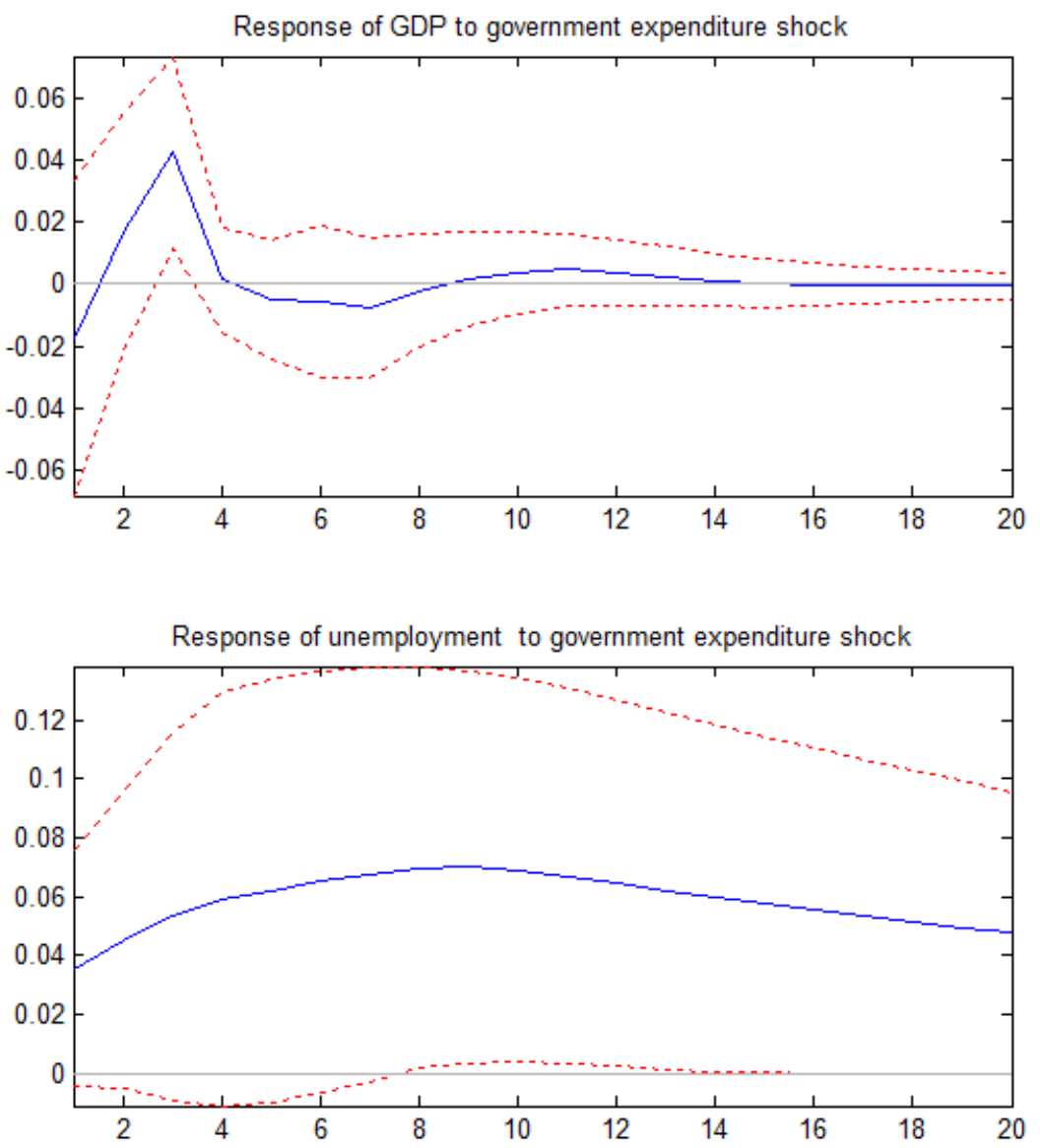


\subsection{Comparison of flexible and rigid labour markets}

When the impulse response plot of the flexible and rigid labour markets are shown on the same scale as done in Figure 9, the difference can be seen more clearly. I find an explicit distinction between two regimes. The results show that impulse responses to a one percentage point government expenditure shock exhibit non-linear effects as the response of the economic outcome change substantially with the flexibility of the labour market. Even though the government expenditure shock has growth stimulating impacts in both markets, it is higher, more significant and persistent in the flexible labour regime. Thus, this result confirms that relaxing the regulations in the labour markets help economies to react and benefit from the fiscal stimulus more effectively, which supports my main hypothesis. Additionally, flexibility in the labour market contributes a significant fall in the overall unemployment of the economies. This result is consistent with the evidence from existing literature, such as Bernal-Verdugo et al. (2012), indicating that increasing labour market flexibility has a significant negative effect on unemployment rate. The regime specific results are also consistent with panel results presented in the previous subsection.

Figure 10 reports the cumulative responses of GDP to government expenditure shock. The plots yield further support for the findings. The overall effect on real GDP per capita is expansive in the flexible labour market regime, even in the long run; whereas it is not that different from zero for the highly regulated markets. As the cumulative effect is around $0.4 \%$ after the second quarters for the flexible regime, it is around zero at the same period for the rigid case. Thus, the cumulative responses also confirm that the fiscal stimulus impact on GDP is larger and more persistent in the flexible labour markets compared to the rigid ones.

\subsection{Effects on GDP components}

In this section, the effects of government spending shock on GDP components, namely private consumption and investment, are discussed and compared in flexible and rigid labour markets. Figure11 shows the impulse responses for both regimes. It is seen that the responses for both of 
Figure 9: Comparison of two regimes

(a) Flexible
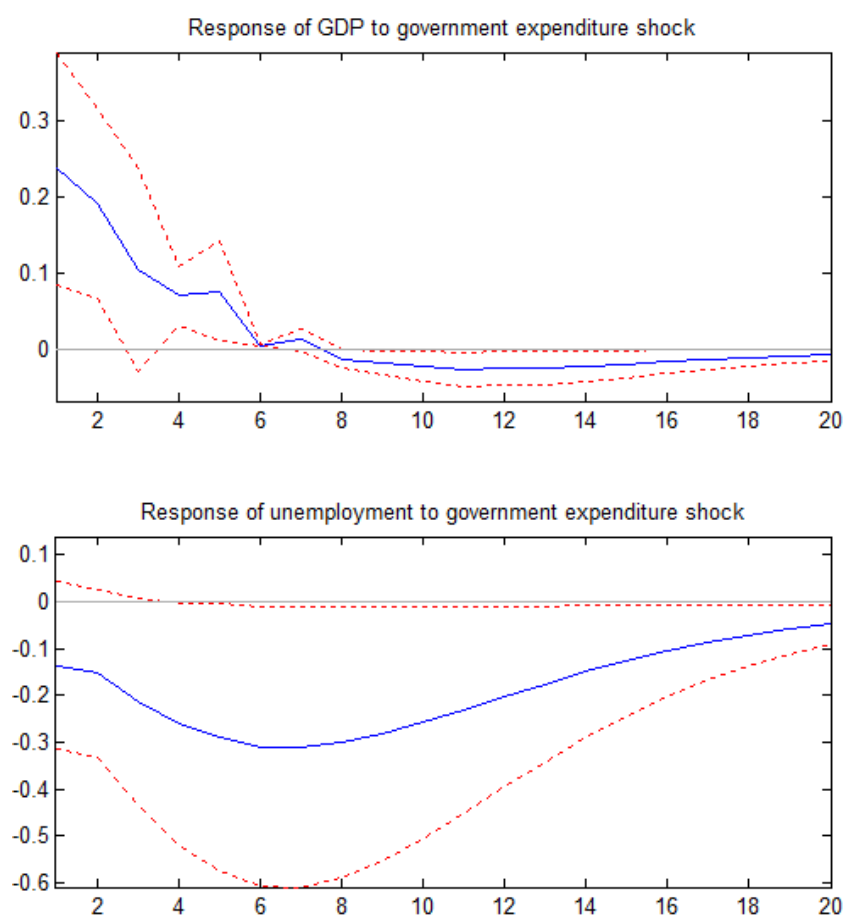

(b) Rigid
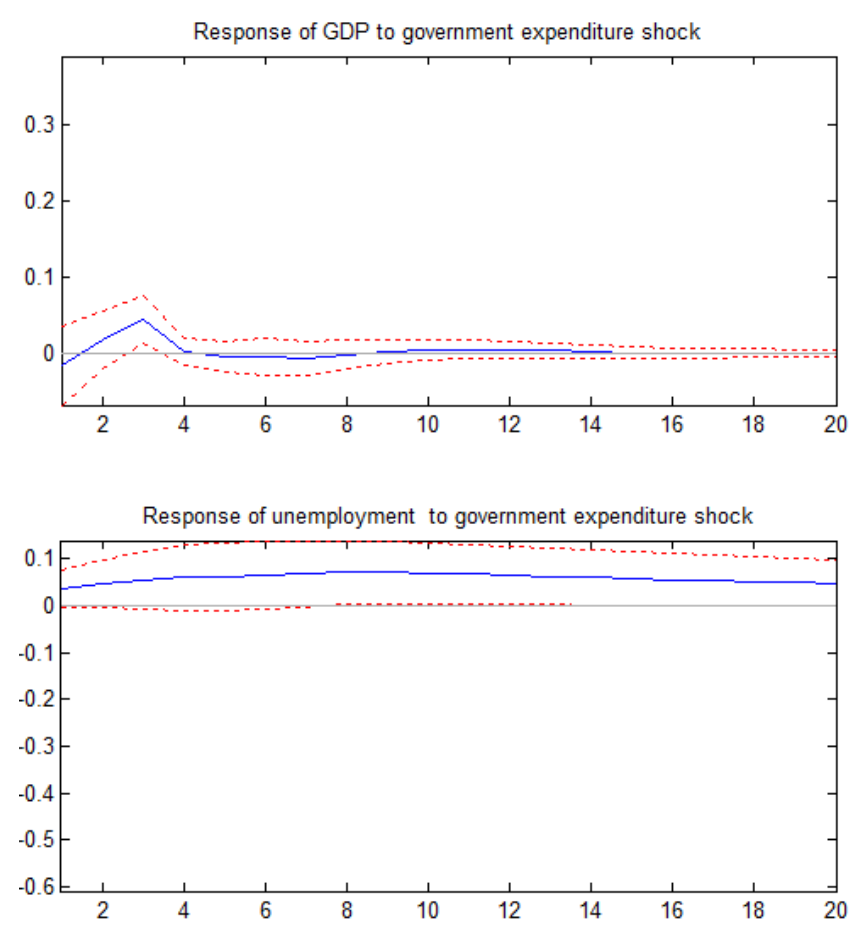

components resemble largely the responses of GDP, whereas it is also the case that the behaviour of private consumption is muted compared to the GDP responses.

As can be observed, there is a marked difference in the response of both private consumption and investment to government expenditure shock across different labour market regimes, which is consistent with the previous results. Even though, consumption and investment respond positively to a shock in government expenditure in both regimes, the responses are much more effective for flexible labour markets. While private consumption, seen in the first row of Figure 11, increases up to around 0.25 p.p. in the flexible labour markets and the positive impact is statistically significant, the impact is not that different from zero in the rigid ones. Private investment responds positively to government expenditure shock in both regimes and the impact is much stronger compared to the private consumption case. In the flexible labour markets, investment reaches a peak at 0.4 p.p. in the second period and this positive response is statistically 
Figure 10: Cumulative responses of GDP to government expenditure shock

(a) Flexible

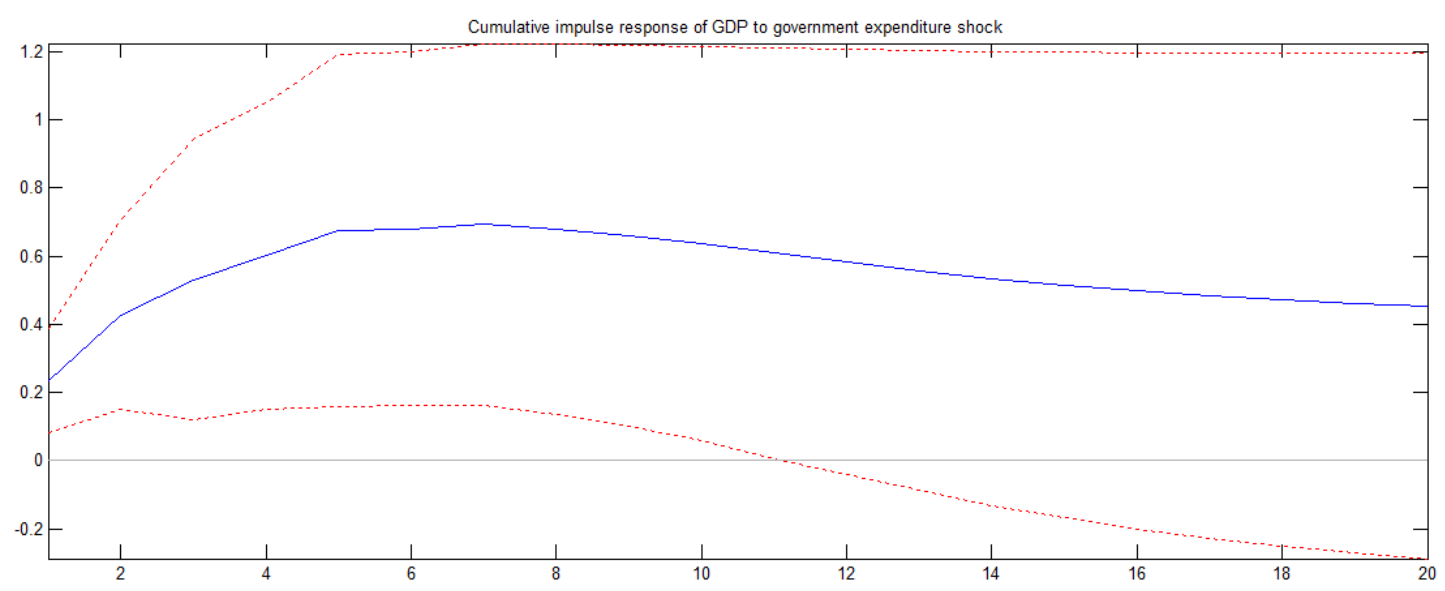

(b) Rigid

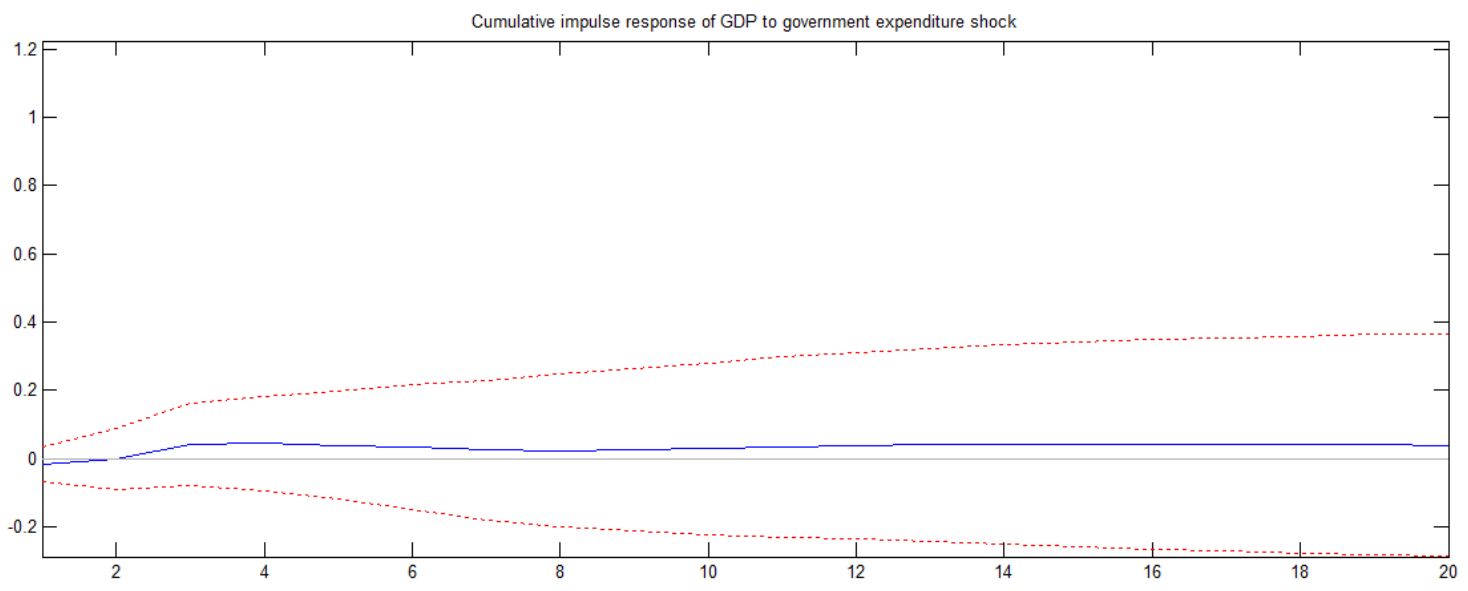

significant for most of the considered periods. On the other side, private investment increases up to 0.1 p.p. around the third quarter in the rigid labour markets and the effect is only significant between the 3 nd and the 6 th quarter. The finding of a positive response of private consumption and investment is consistent with the empirical findings of the existing literature, such as Fatás and Mihov (2001), Giordano et al. (2007), Galí et al. (2007).

Thus, as there is a determined increase in economic activity through positive responses of private consumption and investment for flexible labour markets, there is no significant improvement 
Figure 11: Responses of private consumption and investment

(a) Response of private consumption in flexible labour market

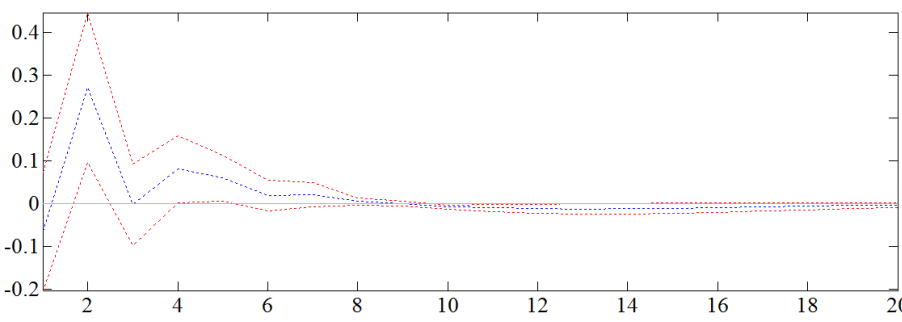

(c) Response of private investment in flexible labour market

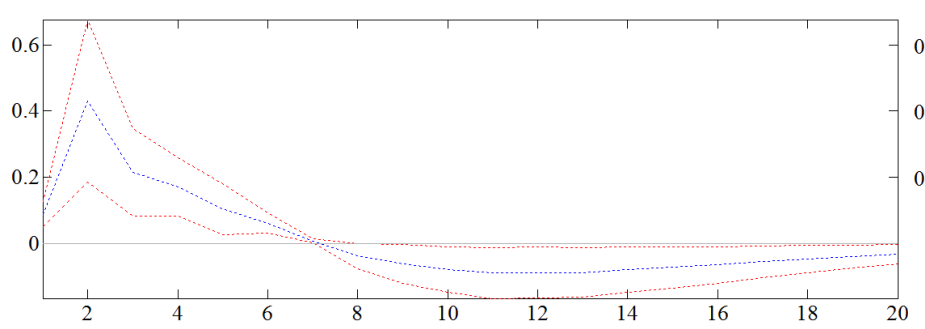

(b) Response of private consumption in rigid labour market

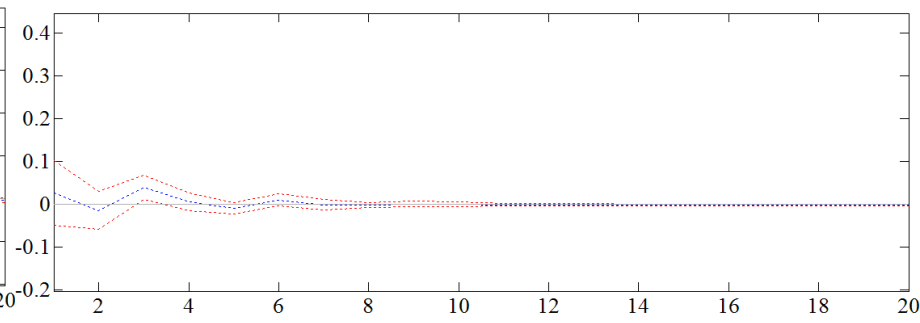

(d) Response of private investment in rigid labour market

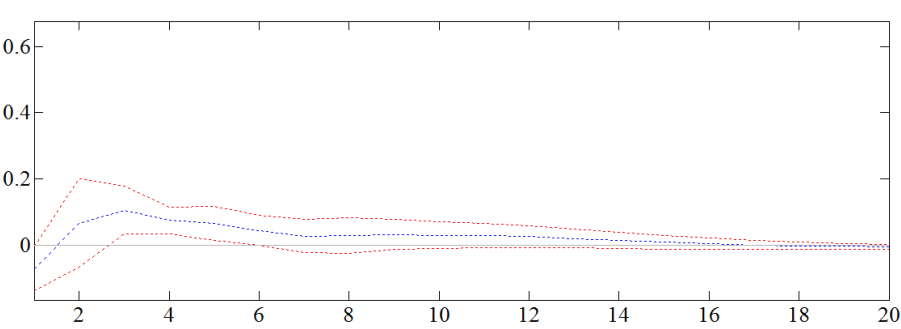

in the output of rigid labour markets. The cumulative responses reported in Figure12 confirms that the responses are much larger in the flexible labour markets than the rigid one as one would expect.

\section{Robustness Checks}

\subsection{Exogenous sample splitting}

To check for the robustness of the sample split, I use an alternative way of sample splitting by using the median value of cross-country mean values of the composite labour market flexibility index by following Turrini (2012). To perform this break down way, I compare the country specific mean of EPL index with median of these averages across the whole panel of countries. As a result, flexible (rigid) countries are the ones with a lower (higher) average value than the sample median. After all, I find that the countries in each regime stay unchanged. Thus, using 
Figure 12: Responses of private consumption and investment

(a) Cumulative response of consumption in flexible labour market (b) Cumulative response of consumption in rigid labour market
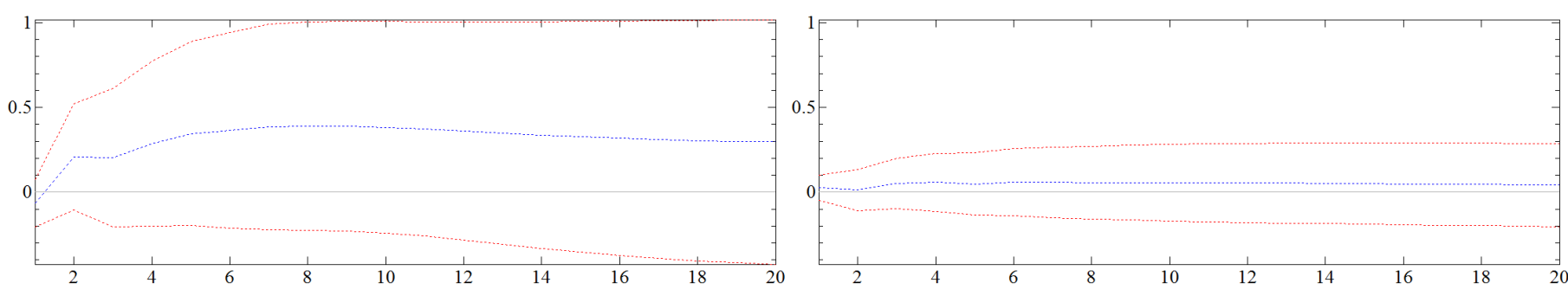

(c) Cumulative response of investment in flexible labour market

(d) Cumulative response of investment in rigid labour market
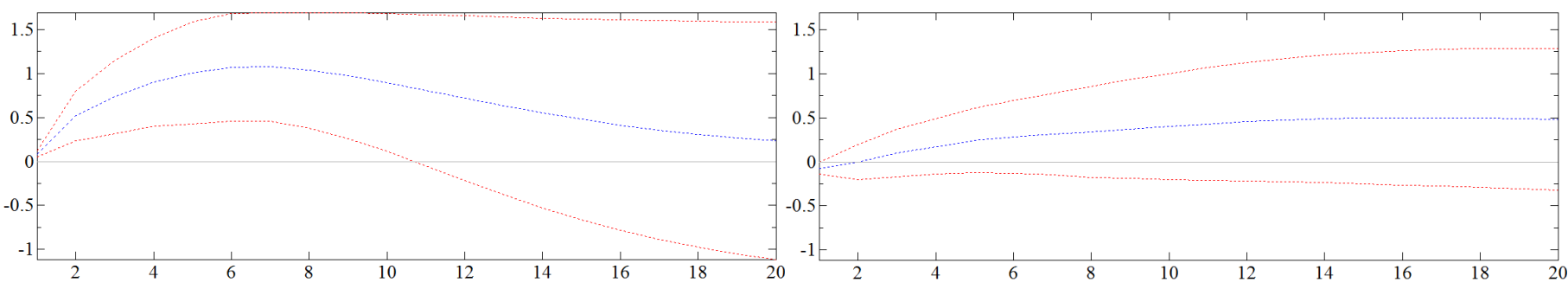

an alternative way of sample splitting has no impact on the sampling.

\subsection{Excluding the recent recession period}

Recently there is a big debate in the fiscal policy literature on the effects of fiscal shocks over business cycle. The recent studies by Auerbach and Gorodnichenko (2012) and Candelon and Lieb (2013), focus on the output response to fiscal policy in, so to say, bad and good times. For robustness checks, I take into account business cycle fluctuations, as well and check whether my results remain robust once I exclude the recent recession period, which corresponds to the last 12 quarters, from my analysis. As it can be observed from Figure 13, the results for both of the regimes do not show any drastic changes after the exclusion. The significant impact of fiscal stimulus on GDP and negative impact on the overall unemployment remain in the flexible labour markets, whereas the response on GDP is again found relatively smaller, less persistent and significant for rigid regime and the unemployment rate increases in response to the expenditure shock. There is only slight changes in the impacts, as the responses of GDP increases slightly in 
both of the markets compared to the full-period estimation results but this does not change the main conclusion for the results based on the comparison of the two markets.

Figure 13: Impulse Responses in 1999-2009

(a) Flexible
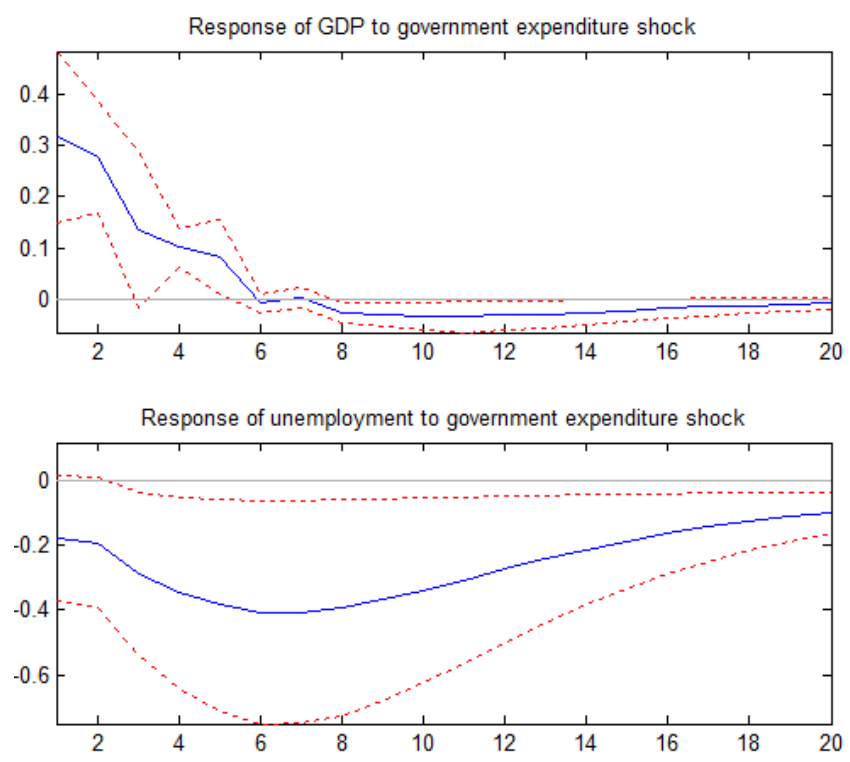

(b) Rigid
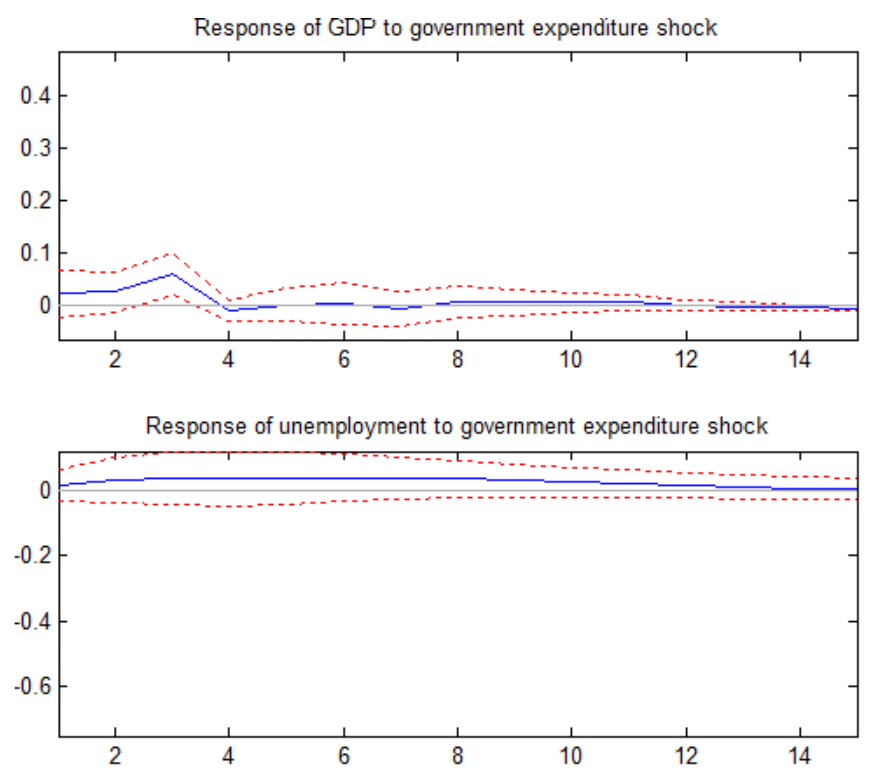


\section{Conclusion}

The aim of this paper is to explore the effects of government expenditure shocks on the economic activity by taking into account the differences in the labor market structure. The research question is whether fiscal stimulus impact differ for flexible and rigid labour markets. By answering this question, I contribute to the recent debate on the macroeconomic effects of fiscal stimuli on economic output.

My main results are as follows. The impulse response of GDP to government spending shock is positive and more effective in flexible labour markets, whereas it appears to have less impact in the rigid regime. The results indicate that as the labour markets get more flexible, the impact on the output gets more persistent. It is also found that fiscal stimulus leads to higher overall unemployment in highly regulated countries. This finding confirms the evidence from the existing literature implying that rigid labour market structure is associated with low job creation rate for the unemployed individuals and increasing labour market flexibility has a significant negative effect on unemployment rate. As labour markets get flexible, government expenditure shocks trigger a stronger increase in the new job creation rate, which leads to reduction in the overall unemployment. My findings remain robust when I do some robustness checks, such as excluding the period of the recent recession period and using an alternative measure for sample splitting.

The responses for the GDP components support the previous results by detecting a marked difference in the response of both private consumption and investment to government expenditure shock across different labour market regimes. Consumption and investment respond positively to a shock in government expenditure in both regimes and the responses are much more effective for flexible labour markets.

The results suggest that flexibility of the labour market plays a crucial role for the success of the fiscal stimulus. In case of high employment protection and heavily regulated markets, employers may find it less profitable to react to fiscal stimuli due to the restrictions on the hiring and firing processes. Thus, this restricts the effectiveness of the fiscal policy implementations 
in labour markets that are subject to rigid structures. Relaxing the regulations may help for achieving more efficient fiscal stimulus impacts. 


\section{Appendix}

\subsection{Details on data}

Table 3: Data used

\begin{tabular}{cccc}
\hline \hline Variable & Database & Source & Countries \\
\hline Government expenditure & Quarterly Non-financial Acc. & Eurostat & all but the US \\
& National income and products & US Bureau of Econ. Analysis & the US \\
Government revenue & Quarterly Non-financial Acc. & Eurostat & all but the US \\
& National income and products & US Bureau of Econ.Analysis & the US \\
Real GDP & Quarterly National Acc. & OECD & all \\
Unemployment & Labour Market Statistics & OECD & all \\
Consumer Price Index & Main Economic Indicators & OECD & all \\
Population & Main Economic Indicators & OECD & all \\
EPL & Employment Database & OECD & all \\
\hline \hline
\end{tabular}




\section{References}

Agnello, L., Castro, V., Tovar Jalles, J., and Sousa, R. M. (2014). Fiscal adjustments, labour market flexibility and unemployment. Economics Letters, 124(2):231-235.

Amisano, G. and Giannini, C. (1997). Topics in Structural VAR Econometrics. Springer.

Andrews, D. W. K. (1993). Tests for Parameter Instability and Structural Change with Unknown Change Point. Econometrica, 61(4):821-56.

Arin, K. P. and Spagnolo, N. (2011). Short-term growth effects of fiscal policy revisited: A Markov-switching approach. Economics Letters, 110(3):278-281.

Auerbach, A. J. and Gorodnichenko, Y. (2012). Measuring the Output Responses to Fiscal Policy. American Economic Journal: Economic Policy, 4(2):1-27.

Baum, A. and Koester, G. B. (2011). The impact of fiscal policy on economic activity over the business cycle - evidence from a threshold VAR analysis.

Bernal-Verdugo, L. E., Furceri, D., and Guillaume, D. (2012). Labor Market Flexibility and Unemployment: New Empirical Evidence of Static and Dynamic Effects. Comparative Economic Studies, 54(2):251-273.

Betcherman, G. (2013). Labor market institutions: A review of the literature. Background paper for the World Development Report 2013, The World Bank.

Blanchard, O. and Perotti, R. (2002). An Empirical Characterization Of The Dynamic Effects Of Changes In Government Spending And Taxes On Output. The Quarterly Journal of Economics, 117(4):1329-1368.

Boeri, T. and Brücker, H. (2011). Shorttime work benefits revisited: some lessons from the Great Recession. Economic Policy, 26(68):697-765.

Brückner, M. and Pappa, E. (2012). Fiscal Expansions, Unemployment, And Labor Force Participation: Theory And Evidence. International Economic Review, 53(4):1205-1228. 
Candelon, B. and Lieb, L. (2013). Fiscal policy in good and bad times. Journal of Economic Dynamics and Control, 37(12):2679-2694.

Clements, M. P. and Galvão, A. B. (2004). A comparison of tests of nonlinear cointegration with application to the predictability of US interest rates using the term structure. International Journal of Forecasting, 20(2):219-236.

Cogan, J. F., Cwik, T., Taylor, J. B., and Wieland, V. (2010). New Keynesian versus old Keynesian government spending multipliers. Journal of Economic Dynamics and Control, 34(3):281-295.

Corsetti, G. and Müller, G. J. (2006). Twin deficits: squaring theory, evidence and common sense. Economic Policy, 21(48):597-638.

Djankov, S., Porta, R. L., de Silane, F. L., Shleifer, A., and Botero, J. (2004). The Regulation of Labor. Quarterly Journal of Economics, 119(4):133982.

Faia, E., Lechthaler, W., and Merkl, C. (2013). Fiscal stimulus and labor market policies in Europe. Journal of Economic Dynamics and Control, 37(3):483-499.

Fatás, A. and Mihov, I. (2001). The Effects of Fiscal Policy on Consumption and Employment: Theory and Evidence. (2760).

Fazzari, S., Morley, J., and Panovska, I. (2013). State-Dependent Effects of Fiscal Policy. (201227A).

Galí, J., Lòpez-Salido, J. D., and Vallés, J. (2007). Understanding the Effects of Government Spending on Consumption. Journal of the European Economic Association, 5(1):227-270.

Galvao, A. B. C. (2006). Structural break threshold VARs for predicting US recessions using the spread. Journal of Applied Econometrics, 21(4):463-487.

Giordano, R., Momigliano, S., Neri, S., and Perotti, R. (2007). The effects of fiscal policy in Italy: Evidence from a $\{\mathrm{VAR}\}$ model . European Journal of Political Economy, 23(3):707 733. 
Girouard, N. and Andre, C. (2005). Measuring Cyclically-adjusted Budget Balances for OECD Countries. (434).

Gomez-Salvador, R., Messina, J., and Vallanti, G. (2004). Gross job flows and institutions in Europe. Labour Economics, 11(4):469-485.

Heyes, J. and Lewis, P. C. (2013). Employment protection under fire: Labour market deregulation and employment in the european union. Economic and Industrial Democracy.

IILS (2011). A Review of Global Fiscal Stimulus. EC-IILS Joint Discussion Paper Series, (5).

Ilzetzki, E., Mendoza, E. G., and Végh, C. A. (2013). How big (small?) are fiscal multipliers? Journal of Monetary Economics, 60(2):239-254.

Lazear, E. P. (1990). Job Security Provisions and Employment. The Quarterly Journal of Economics, 105(3):699-726.

Monacelli, T., Perotti, R., and Trigari, A. (2010). Unemployment fiscal multipliers. Journal of Monetary Economics, 57(5):531-553.

Mountford, A. and Uhlig, H. (2009). What are the effects of fiscal policy shocks? Journal of Applied Econometrics, 24(6):960-992.

Nickell, S. (1997). Unemployment and Labor Market Rigidities: Europe versus North America. Journal of Economic Perspectives, 11(3):55-74.

OECD (2004). Employment Protection Regulation and Labour Market Performance. in OECD Employment Outlook 2004, OECD Publishing.

OECD (2013). Protecting jobs, enhancing flexibility: A new look at employment protection legislation. in OECD Employment Outlook 2013, OECD Publishing.

Olney, W. W. (2013). A race to the bottom? Employment protection and foreign direct investment. Journal of International Economics, 91(2):191-203. 
Pappa, E. (2009). The Effects Of Fiscal Shocks On Employment And The Real Wage. International Economic Review, 50(1):217-244.

Perotti, R. (1999). Fiscal Policy In Good Times And Bad. The Quarterly Journal of Economics, 114(4):1399-1436.

Perotti, R. (2005). Estimating the effects of fiscal policy in OECD countries. Proceedings.

Pesaran, M. H. and Smith, R. (1995). Estimating long-run relationships from dynamic heterogeneous panels. Journal of Econometrics, 68(1):79-113.

Ramey, V. A. (2011). Identifying Government Spending Shocks: It's all in the Timing. The Quarterly Journal of Economics, 126(1):1-50.

Ramey, V. A. and Shapiro, M. D. (1998). Costly capital reallocation and the effects of government spending. Carnegie-Rochester Conference Series on Public Policy, 48(1):145-194.

Saint-Paul, G. (2004). Why are European Countries Diverging in their Unemployment Experience? Journal of Economic Perspectives, 18(4):49-68.

Sims, C. A. (1980). Macroeconomics and Reality. Econometrica, 48(1):1-48.

Tagkalakis, A. (2013). The unemployment effects of fiscal policy: recent evidence from Greece. IZA Journal of European Labor Studies, 2(1):1-32.

Tridico, P. (2012). The impact of the economic crisis on the EU labour market: a comparative perspective. (0153).

Tsay, R. S. (1989). Testing and Modeling Threshold Autoregressive Processes. Journal of the American Statistical Association, 84(405):231-240.

Tsay, R. S. (1998). Testing and Modeling Multivariate Threshold Models. Journal of the American Statistical Association, 93(443):1188-1202.

Turrini, A. (2012). Fiscal Consolidation in Reformed and Unreformed Labour Markets: A Look at EU Countries. Institute for the Study of Labor, IZA Policy Papers,47. 
Uhlig, H. (2005). What are the effects of monetary policy on output? Results from an agnostic identification procedure. Journal of Monetary Economics, 52(2):381-419.

Walz, G., Buiskool, B., Collewet, M., and de Koning, J. (2012). Short-time working arrangements during the crisis and lessons to learn. Panteia.

Wolff, G. B., Tenhofen, J., and Heppke-Falk, K. H. (2006). The macroeconomic effects of exogenous fiscal policy shocks in Germany: a disaggregated SVAR analysis. Discussion Paper Series 1: Economic Studies 2006,41, Deutsche Bundesbank, Research Centre.

Zhang, Y., Thelen, N., and Rao, A. (2011). Social Protection in Fiscal Stimulus Packages: Some Evidence. A UNDP/ODS Working Paper. 


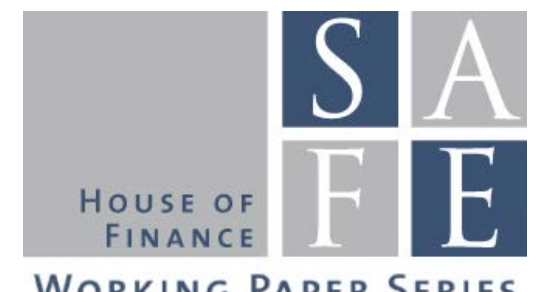

WORKINg PAPER SERIES

\section{Recent Issues}

No. 89 Julia Braun, Alfons J. Weichenrieder

No. 88 Ester Faia, Beatrice Weder di Mauro

No. 87 Iñaki Aldasoro, Domenico Delli Gatti, Ester Faia

No. 86 Agar Brugiavini, Danilo Cavapozzi, Mario Padula, Yuri Pettinicchi

No. 85 Holger Kraft, Claus Munk, Sebastian Wagner

No. 84 Raimond Maurer, Olivia S. Mitchell, Ralph Rogalla, Tatjana Schimetschek

No. 83 Patrick Grüning

No. 82 Edgar Vogel, Alexander Ludwig, Axel Börsch-Supan

No. 81 Jens-Hinrich Binder

No. 80 Enrique G. Mendoza, Linda L. Tesar, Jing Zhang

No. 79 Òscar Jordà, Alan M. Taylor

No. 78 Harris Dellas, Dirk Niepelt

No. 77 Benjamin Born, Gernot J. Müller, Johannes Pfeifer

No. 76 Alberto Alesina, Carlo Favero, Francesco Giavazzi

No. 75 Markus Behn, Rainer Haselmann, Vikrant Vig
Does Exchange of Information between Tax Authorities Influence Multinationals' Use of Tax Havens?

Cross-Border Resolution of Global Banks

Bank Networks: Contagion, Systemic Risk and Prudential Policy

Financial education, literacy and investment attitudes

Housing Habits and Their Implications for LifeCycle Consumption and Investment

Will They Take the Money and Work? An Empirical Analysis of People's Willingness to Delay Claiming Social Security Benefits for a Lump Sum

International Endogenous Growth, Macro Anomalies, and Asset Prices

Aging and Pension Reform: Extending the Retirement Age and Human Capital Formation

Resolution Planning and Structural Bank Reform within the Banking Union

Saving Europe?: The Unpleasant Arithmetic of Fiscal Austerity in Integrated Economies

The Time for Austerity: Estimating the Average Treatment Effect of Fiscal Policy

Austerity

Does Austerity Pay Off?

The Output Effect of Fiscal Consolidation Plans

The Limits of Model-Based Regulation 